\title{
DIE ROL VAN DIE EERSTE SUID- AFRIKAANSE INFANTERIEDIVISIE TYDENS DIE GEVEGTE BY EL ALAMEIN, JULIE TOT NOVEMBER 1942
}

Kmdt C.J. Jacobs*

DEEL 1: DIE EERSTE SLAG VAN EL ALAMEIN, 1 - 30 JULIE 1942

The role of the First South African Infantry Division in the first Battle of El Alamein, 130 July 1942. The First Battle of El Alamein (1-30 July 1942) was the turning-point in the course of the Second World War in North Africa. Under the command of Gen. C.J.E. Auchinleck, the British Eigth Army finally succeeded in halting the advance of Erwin Rommel, the able German general, to the Suez Canal. Through drastically changing the British battle strategy, Auchinleck prepared the way for Gen. B.L. (Monty) Montgomery's later triumph at the Second Battle of El Alamein in October 1942. Auchinleck's July success was due in no small manner to the stubborn resistance of the Fifth Indian Division, the First South African Division and the Ninth Australian Division. This prevented Rommel from breaking through the Eighth Army's positions between Ruweisat Ridge and the Mediterranean Sea. These battles also emphasized the leadership quality of Gen. Dan Pienaar and his fellow South African officers.

\section{AGTERGROND}

Die Unie van Suid-Afrika het op 6 September 1939 tot die Tweede Wêreldoorlog toegetree. As Eerste Minister, Minister van Verdediging en Opperbevelvoerder van die Unieverdedigingsmag het vdm. J.C. Smuts ' $n$ belangrike invloed uitgeoefen om Suid-Afrikaanse magte in die Midde-Ooste 'n rol te laat speel.' Hy het besef dat die Geallieerdes nie na die Europese vasteland sou kon terugkeer voordat die Spilmagte uit Noord-Afrika verdryf is nie. ${ }^{2}$

Vanaf Noord-Afrika het die Spilmagte 'n voortdurende bedreiging vir die olievelde van die Persiese Golf ingehou, waarsonder die Britse Ryk se oorlogspoging ernstig benadeel sou wees. Vanaf Egipte was die Britse magte ook geografies in 'n posisie om offensief teen die swakker bondgenoot in die Spilmagalliansie, Italië, op te tree, sodra genoeg magte beskikbaar was. $^{3}$ Gevolglik het die Eerste en Tweede Suid-Afrikaanse Infanteriedivisies en kontingente van die Suid-Afrikaanse Lugmag en Vloot, onder Britse bevel, vanaf 1941 aan operasies in diè gebied deelgeneem. ${ }^{4}$
Suid-Afrikaanse oudgediendes herdenk jaarliks in Oktober saam met oorlogsveterane oor die wêreld heen die Slag van El Alamein. Diè bekende slag wat op 23 Oktober 1942 begin het, was die begin van 'n triomfantlike opmars van die Britse Agste Leër wat die spilmagte tot in Tunisië teruggedryf het. Hierdie aanmars, saam met die landing van 'n gesamentlike Anglo-Amerikaanse mag in November 1942, het die Geallieerdes in staat gestel om met ' $n$ knyptangbeweging, in 1943, die oorgawe van die Spilmagte in Noord-Afrika af te dwing. Gedurende 1942 het daar egter ook nog twee ander, minder bekende, veldslae in die omgewing van $\mathrm{El}$ Alamein plaasgevind waarin die SuidAfrikaanse magte ' $n$ rol gespeel het. Dit was die sogenaamde "Eerste Slag van El Alamein" (1 tot 30 Julie) en die "Slag van Alam Halfa" (31 Augustus tot 7 September).

Die Eerste Slag van El Alamein het 'n oorgangsfase vir die Britse magte in Egipte verteenwoordig. Die voorafgaande tydperk, dws vandat die oorlog op 10 Junie 1940 na Noord-Afrika uitgekring het tot die Agste Leër teen die einde van Junie 1942 


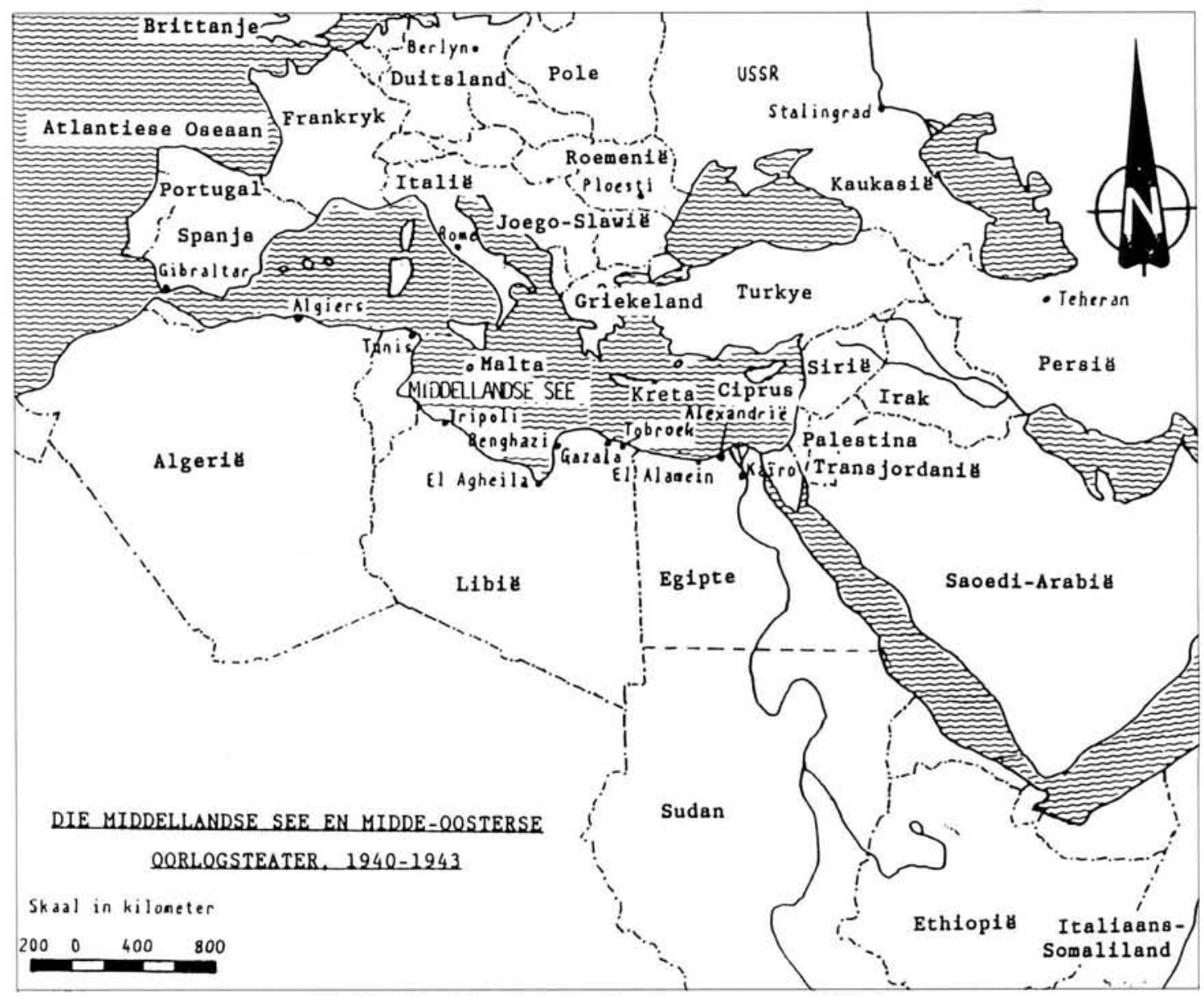

Uit: ISO. Playfair, et al, The Mediterranean and Middle East, Vol 111, Kaart no I

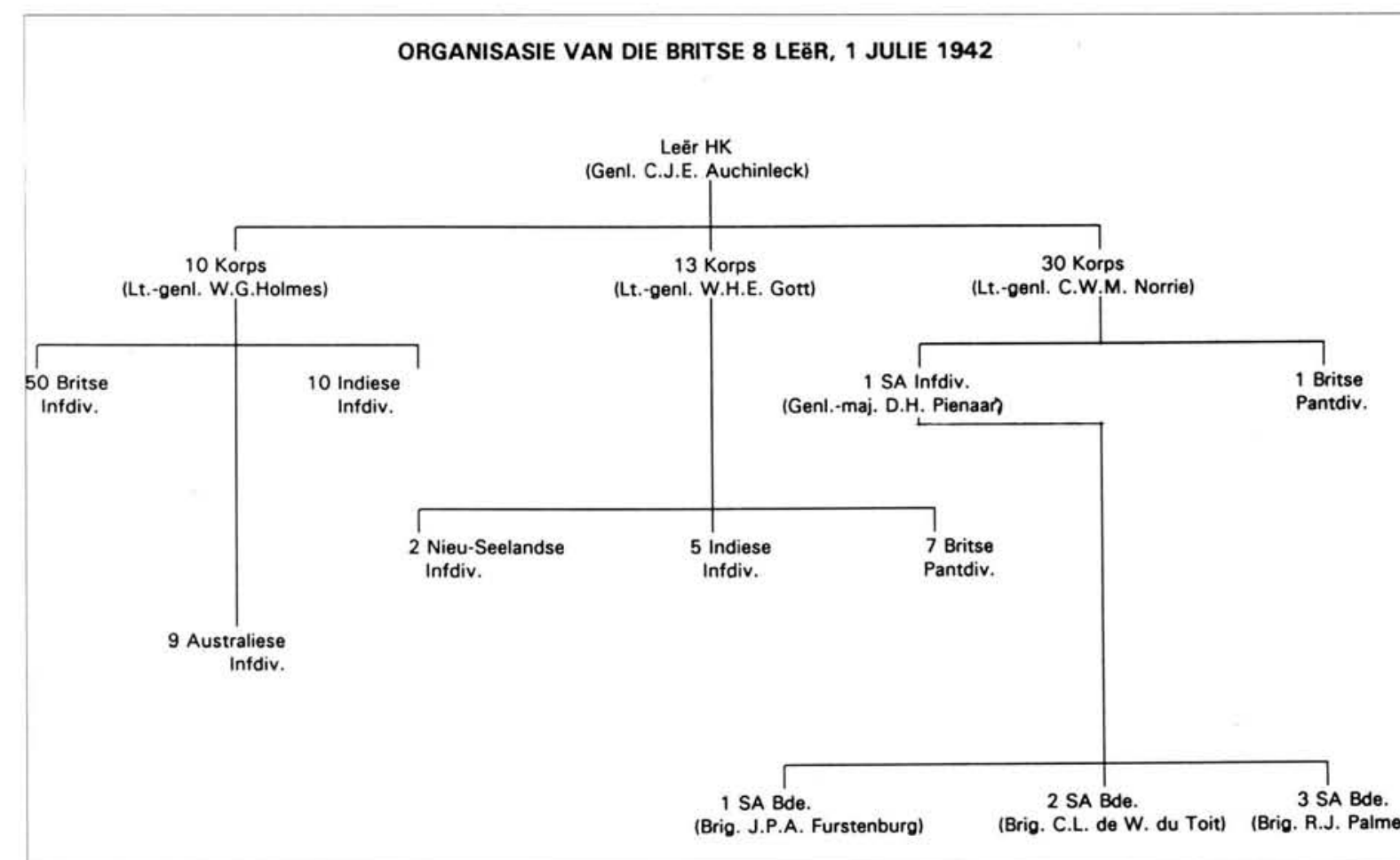

Saamgestel uit Purnell's History of the Second World War, No 7, 3/6 1967, p.1068 (E. Dorman O'Gowan : 1st Alamein The Battle that saved Cairo). 
na El Alamein teruggetrek het, is gekenmerk deur die onvermoë van die Britse aanvoerders om 'n doeltreffende strategie teen die krygsleiding van die legendariese Duitse generaal Erwin Rommel te vind. Tydens die Eerste Slag van El Alamein het die Britse aanvoerder genl. C.J.E. Auchinleck, egter daarin geslaag om Rommel te stuit totdat die Britse magte sterk genoeg was om hom finaal vanaf El Alamein terug te dryf. Hierdie veldslag was dus inderdaad die begin van Rommel se val in Noord-Afrika.

Die Britse Agste Leër het van 1 tot 13 Julie 1942, die dag waarop Rommel se voorlaaste poging om na Alexandrië deur te breek afgeweer is, grotendeels defensief opgetree. Daarna het Auchinleck se magte drie pogings aangewend om deur die Spilmagte se linies te breek en Rommel se Panzerarmee Afrika te vernietig. Die pogings het egter misluk omdat die Britse magte sekere strukturele probleme ondervind het. Auchinleck het wel 'n antwoord gevind om Rommel te stuit, maar nie hoe om sy magte sodanig te verswak dat hulle verplig sou wees om terug te val nie. Diè eer sou sy opvolger, die beroemde genl. B.L. Montgomery ofte wel "Monty", soos hy alom bekend geword het, te beurt val tydens die Tweede Slag van El Alamein.

Teen Augustus was die Britse magte weens hulle aanvalle van die vorige maand uitgeput en het Rommel 'n finale poging aangewend om deur die Britse verdedigingslinie te breek. Dit het gelei tot die Slag van Alam Halfa, waarin Auchinleck se strategie van die eerste gedeelte van Julie met welslae deur Montgomery toegepas is. Anders as Auchinleck, het Montgomery genoeg tyd en versterkings tot sy beskikking gehad om die nodige strukturele aanpassings in die Agste Leër te maak en die aanvalsdoktrine te wysig. Hierdie aanpassings het die groot Britse oorwinning by El Alamein gedurende Oktober tot November 1942 moontlik gemaak.

Historici oorbeklemtoon dikwels die belangrikheid van die Tweede Slag van El Alamein ten koste van die Eerste. Omdat die Suid-Afrikaners tydens die Eerste Slag 'n belangriker rol gespeel het, word hulle aandeel in die stryd in Noord-Afrika dus dikwels nie na waarde geskat nie.

Hierdie artikel sal hopenlik die aandeel van die Eerste Suid-Afrikaanse Infanteriedivisie in die Eerste Slag van El Alamein in perspektief stel.
Die Suid-Afrikaners se aktiwiteite moet noodwendig binne die breër raamwerk van die gevegsontwerp van die Britse Agste Leër bespreek word. Gevolglik word hoofsaaklik op die aktiwiteite van die Britse 30 ste Korps gekonsentreer, onder wie se bevel die Eerste Suid-Afrikaanse Divisie was.

\section{DIE OPPONERENDE MAGTE EN DIE GEVEGSTERREIN}

Die Britse magte in die Midde-Ooste was verantwoordelik vir die verdediging van die volgende gebiede : Egipte, Palestina, Trans-Jordanië, Sirië, Irak en Persië (Iran). Gevolglik het hulle twee fronte gehad om te dek. In Egipte moes Auchinleck as bevelvoerende generaal van alle Britse magte in die Midde-Ooste, Rommel se aanmars na die Nyldelta stuit. Terselfdertyd moes die olievelde van die Persiese Golf teen 'n moontlike Duitse aanmars uit Rusland (via Kaukasië) beveilig word. Die magte wat hier ontplooi is kon eers in Egipte benut word toe dit duidelik geword het dat die Sowjetleërs die Duitse aanmars gestuit het. $^{5}$

Vir die Britse magte in Noord-Afrika het die prentjie teen Julie 1942 nie rooskleurig gelyk nie. Die Agste Leër het die Gazala-linie op 14 Junie begin ontruim en op 21 Junie moes die Tobroek-garnisoen oorgee met die verlies van 33000 man en ' $n$ groot hoeveelheid uitrusting wat deur die Spilmagte buitgemaak is. Aanvanklik sou daar by Mersa Matruh slag gebied word, maar omdat die dorp maklik aan die suidekant omvleuel kon word het genl. Auchinleck besluit om verder na El Alamein terug te val. ${ }^{\circ}$

Daar is wel ' $n$ vertragingsgeveg by Mersa Matruh geveg. Rommel se magte het daarin geslaag om op 26 Junie die Britse Tiende Korps te omsingel, maar hulle was te swak om die Britse magte te verhoed om uit te breek. Nogtans is 6000 Britte krygsgevangene geneem. Mersa Matruh was nog een van ' $n$ reeks neerlae wat die Britte teen Rommel in Noord-Afrika sou ly en die belangrikste kwessie was of die verslae en gedemoraliseerde Agste Leër Rommel sou stuit voordat sy magte die Suez-kanaal kon bereik.?

Die Britse opperbevel in die Midde-Ooste het reeds in 1941 voorlopig besluit dat die El Alamein - Bab el Qattara - Nagb Abu Dweis-lyn die laaste verdedigingslinie voor 


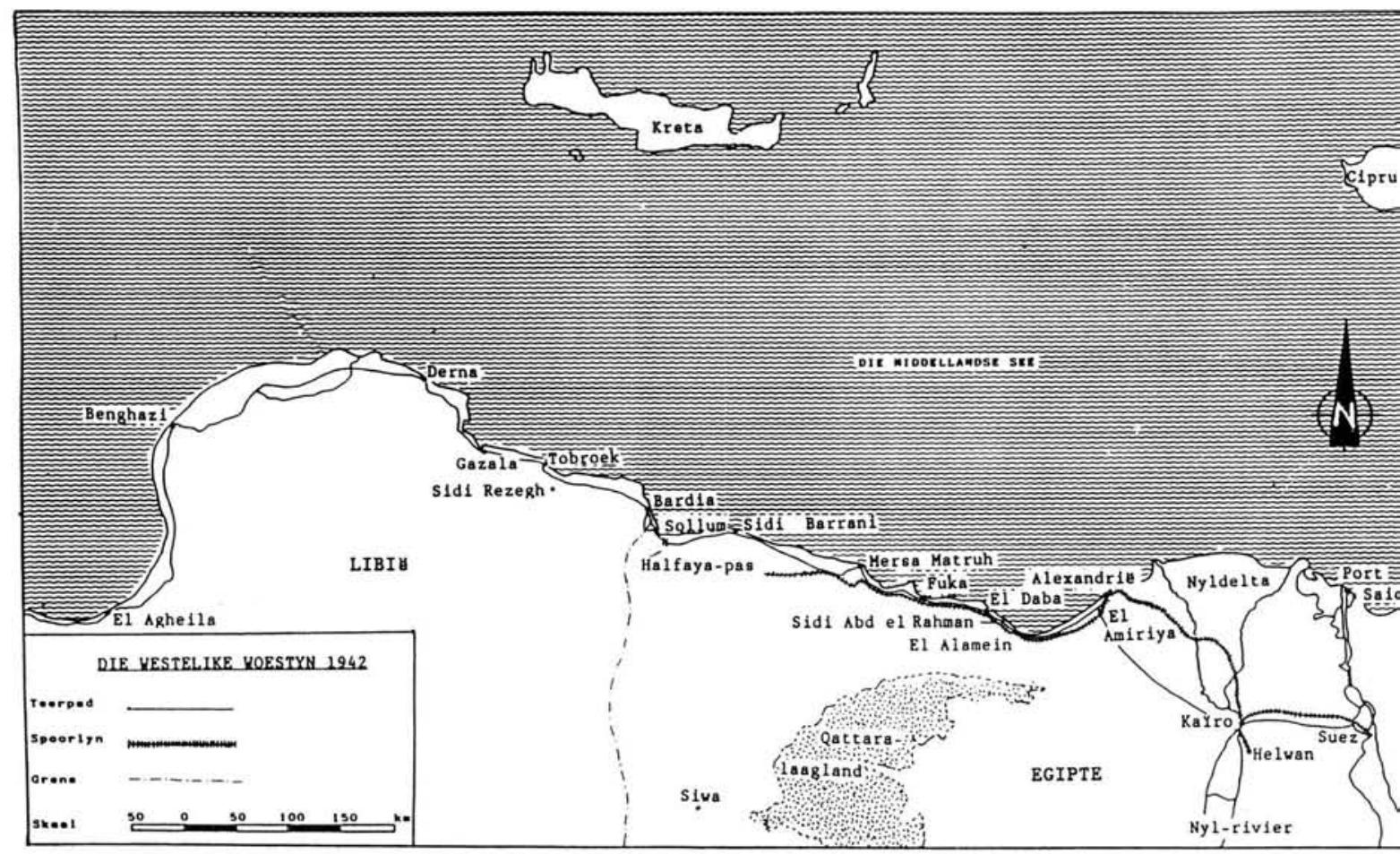

Uit: J.A.I. Agar-Hamilton en L.F.C. Turner, Crisis in the Desert, teenoor p 275.
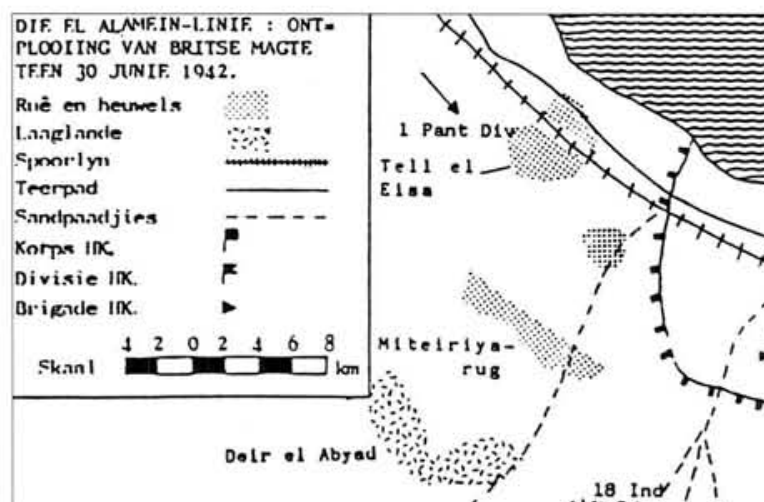
die Nyldelta sou wees. ${ }^{8} \mathrm{Na}$ 'n deeglike terreinondersoek, het Auchinleck op 22 Junie 1942 finaal besluit om by El Alamein met die Agste Leër slag te bied. ${ }^{\circ}$

Die El Alamein-linie was die laaste hindernis voor Rommel se uiteindelike doelwitte in Egipte, d.i. die Nyldelta en die hawe van Alexandrië. Die linie was nie veel meer as 'n lyn op die kaart waarna 'n verswakte Agste Leër teruggeval het. Dit was in skrille kontras met die indruk wat die BBC en die Britse pers by die publiek geskep het. Die Agste Leër sou kwansuis by El Alamein teruggeval het na ' $n$ feitlik ondeurdringbare netwerk van loopgrawe, bunkers en mynvelde wat vanaf die Qattara-laagland tot by die see gestrek het! ${ }^{10}$

Die linie is in twee korps-sektore ingedeel met die Britse 30ste Korps in die noorde en die 13de Korps in die suide." Die noordelike punt van die linie was ongeveer 160 kilometer wes van Alexandrië, teen die Middellandse See by die El Alamein-stasie geleë. ${ }^{12}$ Die sogenaamde El Alameinvesting was 'n divisiebasis wat gedurende 1941 deur die Tweede Suid-Afrikaanse Divisie rondom die stasie ingerig is. In hierdie stadium was dit in ' $n$ verwaarloosde toestand. ${ }^{13}$ Die Eerste Suid-Afrikaanse Divisie was alhier in ' $n$ suidoostelike rigting tot teen die noordelike hang van die Ruweisat-rug ontplooi. ${ }^{14}$

Op die westelike deel van die Ruweisatrug, by Deir el Shein, is die 18de Indiese Brigade, wat pas uit Irak aangekom het in haastig ingerigte verdedigingstellings geplaas. Hiervandaan moes hulle voorlopig 'n gaping van 12 kilometer dek, wat tussen die linkerflank van die Eerste SuidAfrikaanse Divisie en die regterflank van die Britse 13de Korps bestaan het. Die Eerste Britse Pantserdivisie sou na hul aankoms vanaf Mersa Matruh op die oostelike deel van die rug stelling inneem en hierdie gaping vul.

Ten ooste van die Ruweisat-rug het genl. Auchinleck die Agste Leër se taktiese hoofkwartier in die omgewing van die Alam el Halfa-rug ingerig. Verder oos het die Britse Tiende Korps verdedigingstellings in die omgewing van die Nyldelta ingerig met formasies wat by Mersa Matruh swaar verliese gely het, soos die 50ste Britse en Tiende Indiese Divisies.

Die Britse 13de Korps het die gebied suid van die Ruweisat-rug tot teen die Qattara- laagland verdedig. Diè korps het bestaan uit die Tweede Nieu-Seelandse Divisie by Deir el Munassib met sy Sesde Brigade by Bab el Qattara, die Vyfde Indiese Divisiehoofkwartier en die Negende Indiese Brigade by Nagb Abu Dweis, asook die Sewende Britse Pantserdivisie, wat nog op pad was na El Alamein. ${ }^{15}$

Die Qattara-laagland is ongeveer 60 kilometer suidwes van El Alamein. Dit lê, by benadering, 130 meter benede seevlak en beslaan ongeveer 11200 vk. kilometer. ${ }^{16}$ Die oppervlakte van hierdie laagland bestaan grotendeels uit soutpanne en sagte sand wat so ontoeganklik is dat selfs nie eens kamele wat vrag dra daarop kan beweeg nie. ${ }^{17}$ Suid van die laagland strek die Sahara-sandwoestyn wat byna ewe ontoeganklik vir pantser- en motorvoertuie is. ${ }^{18}$

Rommel se enigste hoop was dus om sy magte deur die nou gaping tussen die Middellandse See en die Qattara-laagland te laat breek, voordat die Britse magte tot verhaal kom. ${ }^{19}$ Die Britte se voortdurende terugslae teen Rommel, formasies wat ondersterkte was en die swak ontwikkelde verdedigingstellings het daarop gedui dat die Spilmagte nie veel moeite sou ondervind om deur die Agste Leër se stellings te breek nie.

Die begaafde Rommel se strategie was egter ' $n$ waagstuk. Hy het eerstens nie oor voldoende magte vir die taak voor hande beskik nie. Hy het oor ongeveer 55 Duitse tenks, 2000 infanterie en kanonne beskik, terwyl die Italiaanse magte 30 verouderde tenks, 5500 infanterie en 200 kanonne sterk was. $^{20}$

Tweedens het sy logistieke probleme meegebring dat die Spilmagte slegs 300 ton voorrade per dag ontvang het, terwyl hulle in werklikheid 1500 ton benodig het. Hy kon dus nie bekostig om in 'n uitgerekte uitputtingsgeveg by El Alamein betrokke te raak en die Britse magte op so ' $n$ wyse uit te mergel nie. ${ }^{21}$ Die terrein by El Alamein het dit verder vir Rommel onmoontlik gemaak om soos in die verlede die woestyn in die suide te gebruik om sy vyand te omvleuel. ${ }^{22}$ In die beperkte maneuvreringsruimte tot sy beskikking het alles daarvan afgehang of hy kon deurbreek voordat die Britse pantser die ander komponente van die Agste Leër kon ondersteun. Wanneer Rommel eers in die oop woestyn tussen El Alamein en die Nyldelta was, sou die Spilmagte se meerderwaardigheid in 
mobiele oorlogvoering swaar teen die Agste Leër geweeg het. ${ }^{23}$

Die Agste Leër was egter nie so 'n verslane en gedemoraliseerde mag as wat dit op die oog af gelyk het nie. Alhoewel die Britse militêre posisie in Egipte teen 1 Julie 1942 ver van ideaal was, het sekere faktore in hul guns gewerk. Auchinleck het die nodige aanpassings gemaak, wat die Britse magte wel in staat gestel het om Rommel kort voor sy doelwit te stop. Hy het besef dat verbeterde tenkafweerkanonne, gekonsentreerde artillerie-vuur en die gebruik van landmyne, ondersteun deur pantser en lugkrag reeds vroeër in die woestynoorlog Rommel se aanmars gestuit het. So kon Rommel byvoorbeeld, na herhaalde pogings, nie daarin slaag om Tobroek gedurende 1941 te verower nie. ${ }^{24}$

Auchenleck se strategie was om 'n uitputtingsgeveg teen die Panzerarmee Afrika te voer tot hulle sodanig verswak was en die Britse magte daarteenoor sodanig versterk was dat hulle tot ' $n$ teenoffensief kon oorgaan. Gevolglik het hy dieselfde taktiek waarmee Rommel gedurende 1941 verhoed is om Tobroek te verower, by El Alamein gevolg.

Om dit te laat slaag het Auchinleck drastiese organisatoriese aanpassings gemaak. Divisiebevelvoerders is verantwoordelik gemaak vir die aanwending van artillerie, wat groter konsentrasie van vuur teweeggebring het as voorheen toe die geskut in klein groepies aan kolonnebevelvoerders uitgedeel is. Verder is alle infanterie wat nie oor transport beskik het nie na die Nyldelta gestuur. Die magte wat in die El Alamein-linie ontplooi is was dus redelik mobiel en Rommel se magte sou hulle nie so maklik soos in die verlede in statiese stellings kon vaspen en vernietig nie..$^{25}$

Terwyl Rommel nie op versterkings kon staatmaak nie was troepe en uitrusting reeds vanaf Brittanje op pad terwyl Auchinleck, indien nodig, nog magte uit Irak, Persië en Palestina sou kon onttrek. ${ }^{26}$ Verder het die Britse Lugmag vanaf goed ingerigte basisse in die Nyldelta geopereer, in teenstelling met die Duitse- en Italiaanse Lugmagte wat aangewese was op haastig ingerigte vliegvelde in die woestyn. Trouens, die Britte sou toenemend die lugruim bokant El Alamein beheer, wat Rommel se probleme sou vererger. ${ }^{27}$
Indien Rommel vinnig gespeel het kon hy nog die knoop deurgehak het. Die Britte het nog 150 tenks oorgehad, maar die meeste was ligte tenks wat nie die mas teen Rommel se panzers sou opkom nie. Die Agste Leër het oor slegs 20 Amerikaanse Grant medium tenks in ' $n$ werkende toestand beskik, die enigste tenk wat in daardie stadium teen Rommel se pantser opgewasse was. ${ }^{28} \mathrm{Om}$ alles te kroon het die grootste deel van die Britse pantser eers op 1 Julie by El Alamein aangekom en daardie middag aan die geveg begin deelneem.

Rommel het egter, sonder dat hy dit geweet het, ' $n$ gulde geleentheid om deur te breek deur sy vingers laat glip. Sy tenks was reeds die vorige dag daar, maar omdat hy te min inligting oor die Agste Leër gehad het, het hy na aanleiding van propaganda-uitsendings van die BBC die krag van die Britse verdedigingstellings oorskat. Hy het gevolglik besluit om eers sy magte te hergroepeer en vroegoggend op 1 Julie aan te val. Hy het dus in werklikheid slegs daardie oggend gehad om deur die El Alamein-linie te dring voordat die Britse magte pantsersteun kry. ${ }^{29}$ Die gevegte op die oggend van 1 Julie sou dus van deurslaggewende belang wees en in hierdie situasie het die Eerste SuidAfrikaanse Divisie ' $n$ belangrike rol gespeel.

\section{DIE EERSTE SUID-AFRIKAANSE DIVISIE BY EL ALAMEIN}

Die Eerste Suid-Afrikaanse Divisie het aan die gevegte by Gazala en Mersa Matruh deelgeneem en is teen 25 Junie by El Alamein ontplooi. In ooreenstemming met genl. Auchinleck se strategie is die Derde Brigade in die vesting gehou, maar die Tweede en Eerste Brigades in genoemde volgorde in 'n suidwestelike rigting tot teen die Ruweisat-rug ontplooi. Laasgenoemde twee formasies sou fan as mobiele komponent dien om die Derde Brigade in die vesting te ondersteun. ${ }^{30}$

Die Suid-Afrikaners sou nie ' $n$ maklike taak hê nie. Weens die afgelope maand se gevegte was die Eerste Divisie ongeveer 1/3 van hulle normale sterkte. Die Spilmagte se verowering van Tobroek op 21 Junie was 'n harde slag. Van die garnisoen van 33000 man, was 10722 Suid-Afrikaanse troepe, feitlik die hele Tweede Suid-Afrikaanse Divisie. ${ }^{31}$ Die Eerste Divisie is ook erg verswak deurdat afdelings en toevoegings, wat na die Tweede Suid-Afrikaanse Divisie 


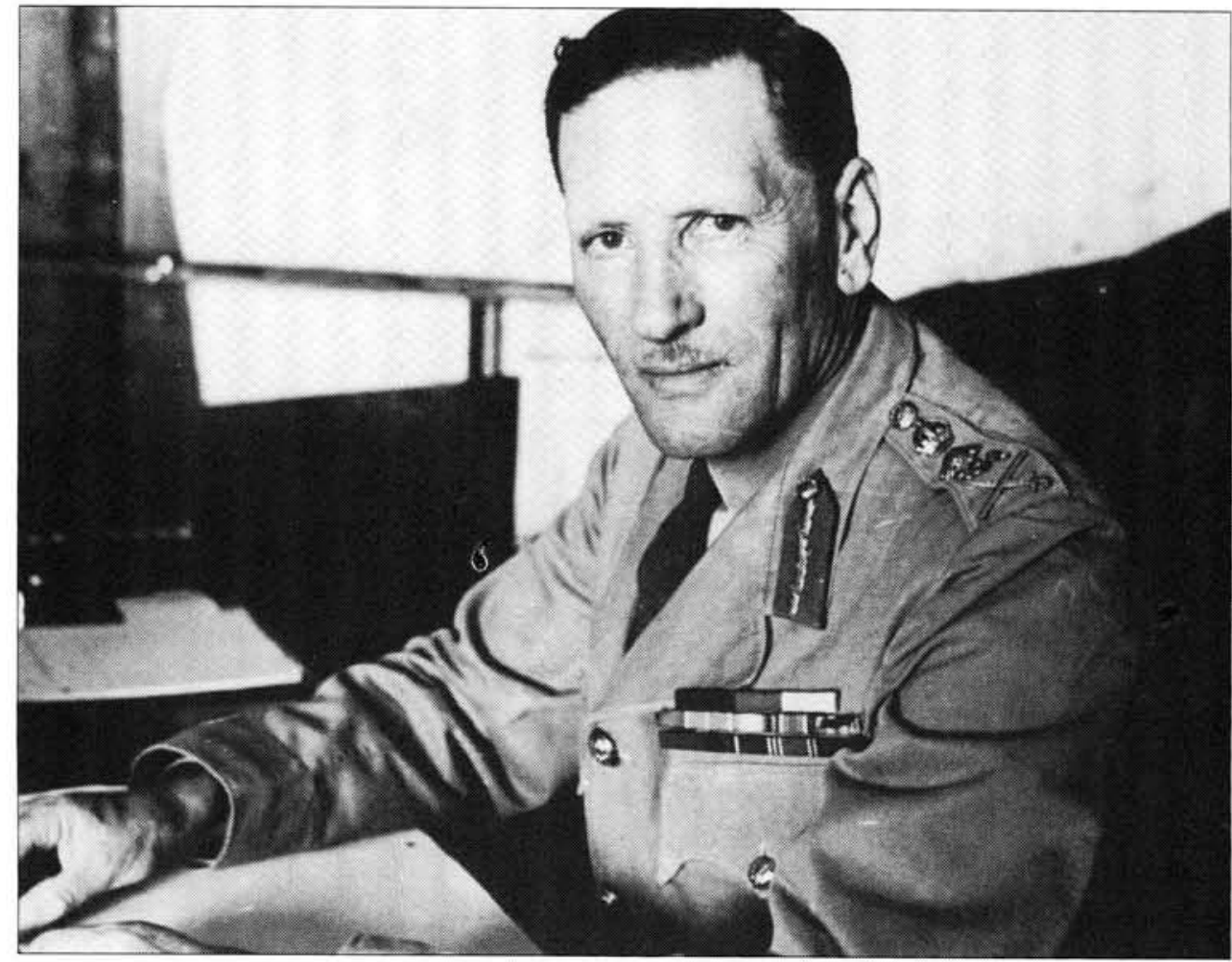

Genl. C.J.E. Auchinleck

Foto's verskaf deur

Direktoraat Dokumentasiediens, SAW.

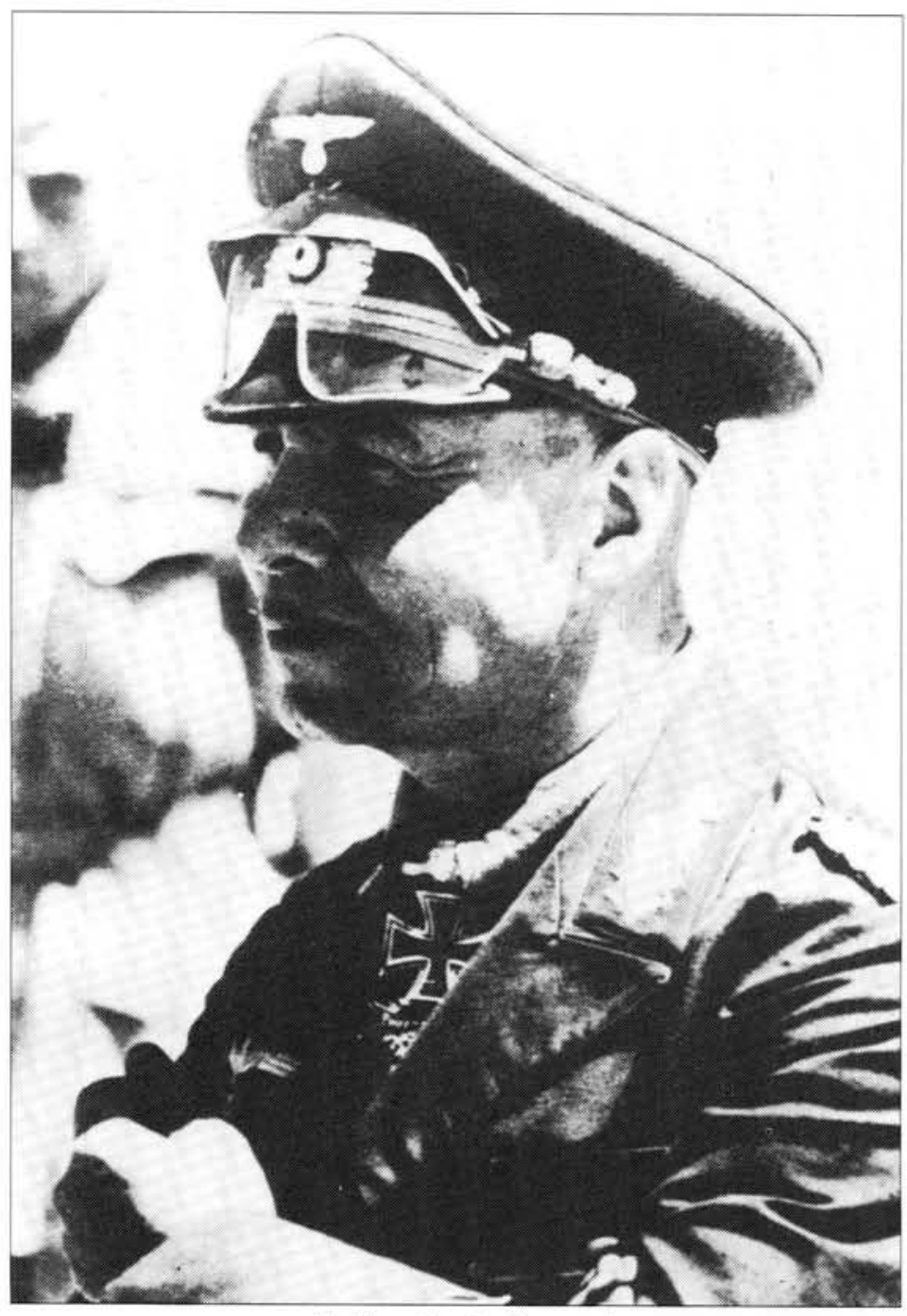

Veldm. Erwin Rommel 
gemaak is, by Tobroek in die slag gebly het. Van die Eerste Divisie se magte het ook by Mersa Matruh in die slag gebly. ${ }^{32}$

Die Eerste Suid-Afrikaanse Divisie het gevolglik by El Alamein ongeveer slegs 3000 tot 4000 man beskikbaar gehad. Hiervan is sommiges na die Nyldelta gestuur om aldaar verdedigingswerke op te rig. ${ }^{33}$

Die Suid-Afrikaners se veldartillerie was ook nie op volle sterkte nie. Die divisie het ' $n$ hele battery by Tobroek verloor. Hulle het gevolglik oor slegs 60, 25-ponder geskut

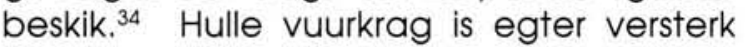
deur die 28, $5.5 \mathrm{dm}$-geskut van die Britse Sewende Mediumregiment wat ook in die omgewing van El Alamein ontplooi is. ${ }^{35}$

\section{ROMMEL SE EERSTE DEURBRAAKPOGING}

Op 1 Julie 1942 het Rommel gepoog om met die Duitse 90ste Ligte Divisie tussen die El Alamein-vesting en die Ruweisat-rug deur te breek en in ' $n$ noordoostelike rigting na die kus op te ruk ten einde die vesting af te sny. Terselfdertyd moes die Duitse Afrika Korps (bestaande uit die 15de en 21 ste Panzerdivisies) suid van die 90ste Ligte Divisie deurbreek en oos van die Britse 13 de Korps inbeweeg. Die res van sy magte het vaspenaanvalle teen die Agste Leër uitgevoer.

Rommel het gehoop om so ' $\mathrm{n}$ gat in die linie te ruk en die Britse formasies dan stuksgewys te verslaan. Alles sou egter daarvan afhang of die 90ste Ligte Divisie kon deurbreek. Indien sy magte die El Alamein-vesting kon verower, sou hulle die El Alamein-linie van noord na suid kon oprol. Dit sou die Britte geen ander keuse gelaat het as om na die Nyldelta terug te val nie. ${ }^{36}$

Die 90ste Ligte Divisie se aanmars het aanvanklik goed verloop. Swak lig en 'n sandstorm, wat sig beperk het, het hulle tot naby die Suid-Afrikaanse stellings laat beweeg voordat hulle opgemerk is. Hierna het hulle egter probleme in die gesig gestaar. In die daaropvolgende geveg het die Eerste Suid-Afrikaanse Divisie herhaalde aanvalle van die Duitse 90ste Ligte Divisie afgeslaan. Daardeur is hulle verhinder om die El Alamein-vesting te omvleuel en die Suid-Afrikaners van die res van die Agste Leër af te sny. ${ }^{37}$

Sekere faktore het in die Suid-Afrikaners se guns gewerk. Dieselfde sandstorm wat die
Duitsers se bewegings verberg het, het ook meegebring dat hulle hul in die stellings van die Derde Suid-Afrikaanse Brigade in die El Alamein-vesting vasgeloop het. Die Duitsers moes toe eers weswaarts onttrek om, soos beplan, suid van die vesting verby te beweeg. Hierdeur is kosbare tyd verloor. Toe die sandstorm opgeklaar het, was die Duitsers maklike teikens in die oop woestyn. Trouens die Suid-Afrikaanse artillerie, mortiere en masjien-gewere het die Duitsers verhinder om enigsins naby hulle stellings te kom. ${ }^{38}$ Gevolglik het geen Suid-Afrikaners op 1 Julie gesneuwel nie., ${ }^{39}$

Die Suid-Afrikaners se taak is ook aansienlik vergemaklik deurdat die Afrika Korps onbewustelik in die 18de Indiese Brigade by Deir el Shein vasgeloop het. Hierdie formasie is vernietig, maar het Rommel se sterkste mag die heeldag besig gehou en genoeg verliese toegedien om sy pantservermoë verder te verswak. Die Afrika Korps het byvoorbeeld teen die einde van die dag slegs 37 diensbare tenks oorgehad. ${ }^{40}$ Gevolglik kon hierdie Duitse mag nie op 1 Julie die Suid-Afrikaners aandurf nie.

Teen die middag van 1 Julie was die Britse Eerste Pantserdivisie op die oostelike rant van die Ruweisat-rug ontplooi en was Rommel se kanse om deur te breek nog skraler. Dit was egter te laat om enigiets aan die lot van die Indiërs by Deir el Shein te verander. ${ }^{41}$

Hierdie gebeure sou egter later 'n nadraai hê. Die Britse bevelvoerders se onverskilligheid teenoor lewensverlies het die SuidAfrikaners reeds sedert die veldtog in OosAfrika gegrief en die lot van die Indiërs by Deir el Shein het hierdie gevoel versterk. ${ }^{42}$ Die Indiërs is byvoorbeeld buite effektiewe aanwendingsafstand van die res van die Agste Leër se artillerie ontplooi. ${ }^{43}$ Terselfdertyd is ' $n$ hulpaanbod van die SuidAfrikaners om ' $n$ ammunisieprobleem wat met hulle aankoms by El Alamein ontstaan het, op te los deur die hoofkwartier van die Agste Leër van die hand gewys. ${ }^{44} \mathrm{Ge}$ durende die geveg is feitlik ook geen poging aangewend om die gedoemde brigade te hulp te snel nie. Hierdie gesindheid van die Britse bevelvoerders sou later lei tot hewige botsings met die bevelvoerder van die Eerste Suid-Afrikaanse Divisie, genl.-maj. D.H. Pienaar.

Die politieke situasie in die Unie het die Suid-Afrikaanse bevelvoerders in 'n nete- 


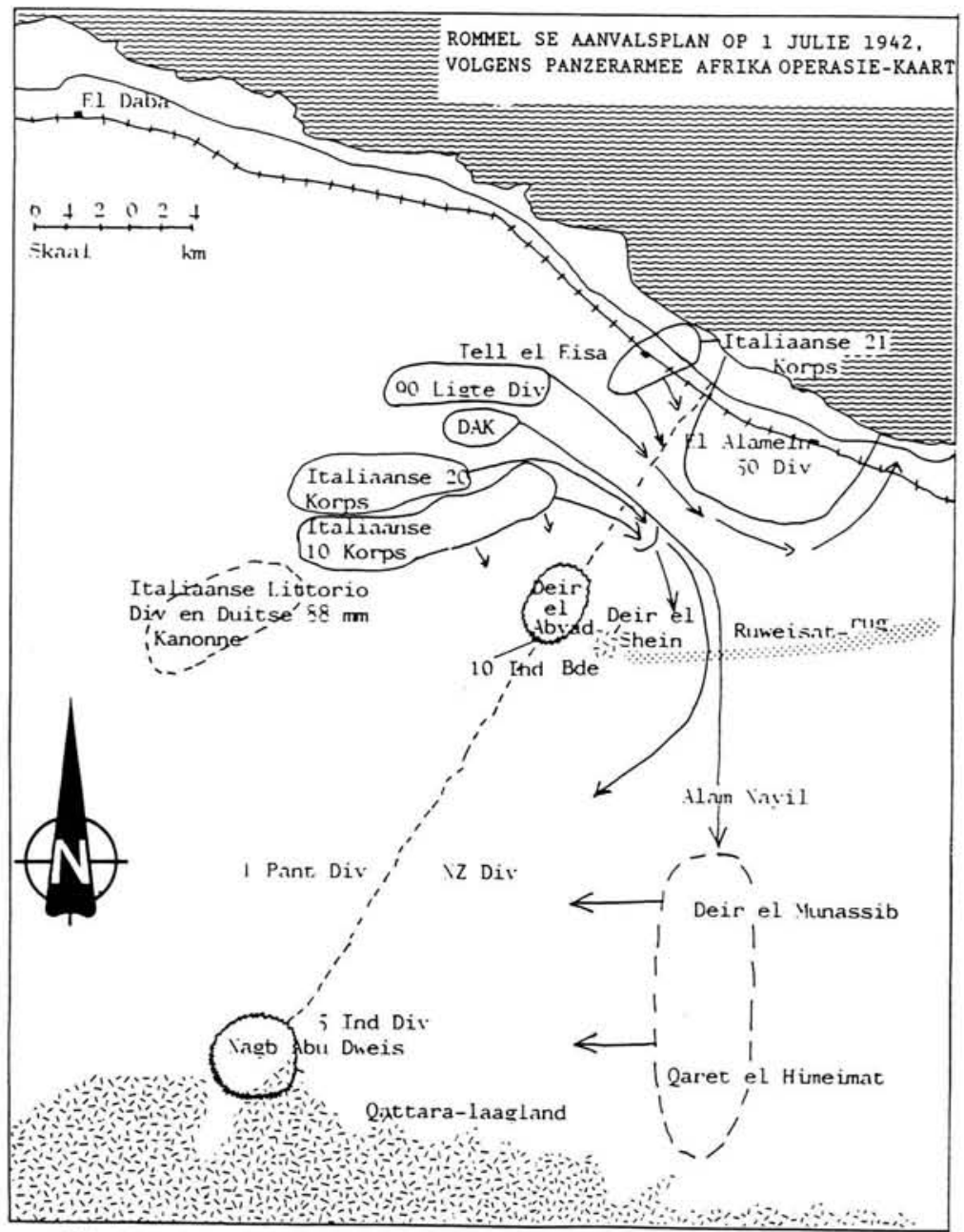

Uit J.A.I. Agar-Hamilton en L.C.F. Turner, Crisis in the Desert, p 286

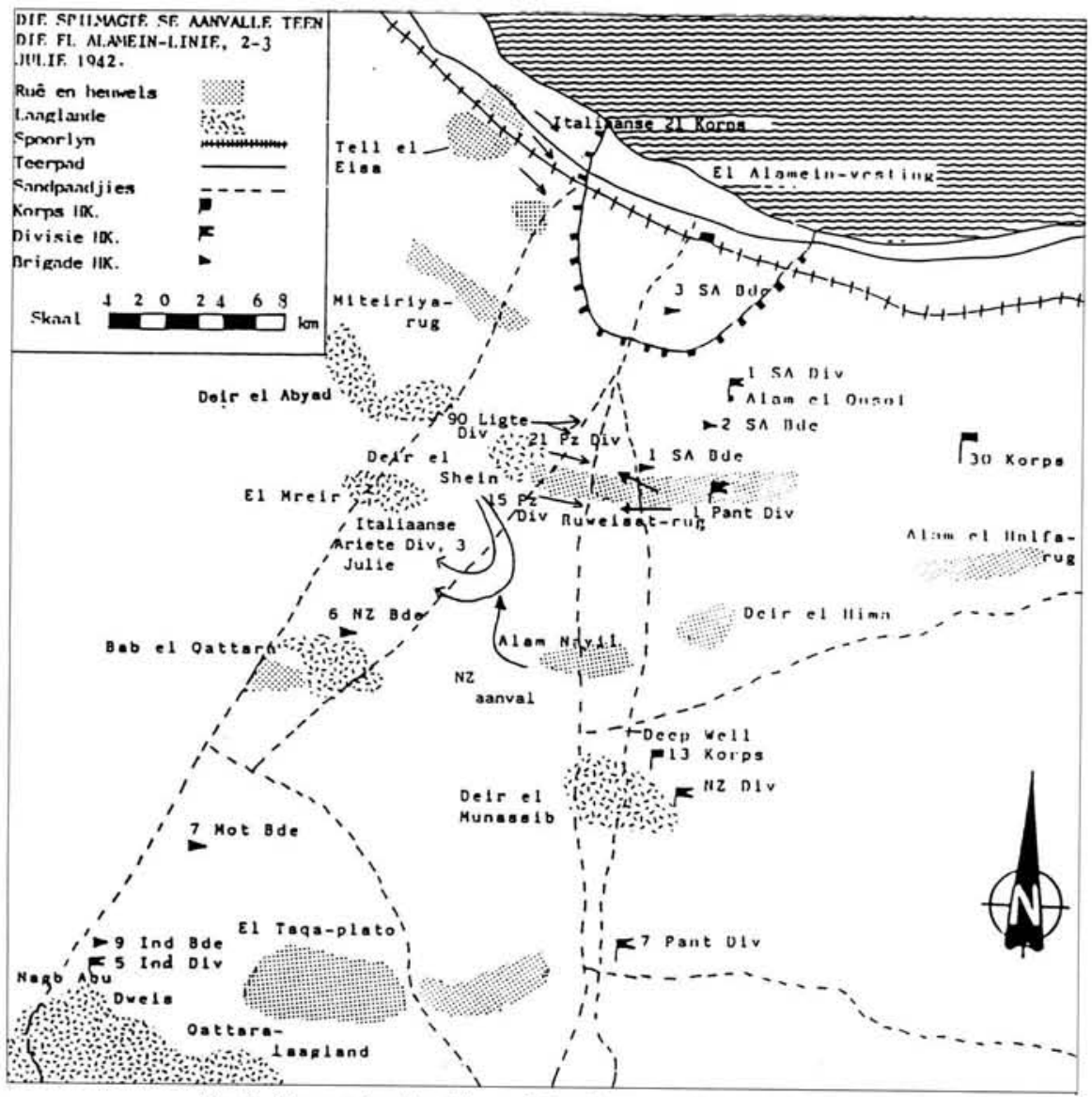

Uir: P. Young (red), Atlas of the Second World War, p 47 
lige situasie geplaas. Die val van Tobroek en die Agste Leër se terugtog na El Alamein het die opponente van die Smutsregering laat moed skep. Op die oog af het dit gelyk asof ' $n$ Duitse oorwinning op hande was en die hoop het onder sommiges bestaan dat die Britse Ryk in die proses sou verbrokkel. ${ }^{45}$ Vir die voorstaanders van verbreking van die bande met Brittanje, moes dit inderdaad na ' $n$ gulde geleentheid gelyk het om hulle ideale te laat realiseer. Enige herhaling van die Tobroek-debakel sou dus in die omstandighede noodwendig vir die SuidAfrikaanse regering ' $n$ verleentheid wees. Dit en die hoë premie wat Pienaar altyd op die welsyn van sy troepe geplaas het, verklaar waarom hy vorentoe met die Britse bevelvoerders sou bots, wanneer hy gevoel het dat die Suid-Afrikaners aan onnodige risiko's blootgestel is.

Teen die aand van 1 Julie het die Spilmagte egter nie verder oos as Deir el Shein gevorder nie en was die Agste Leër in beheer van die situasie. ${ }^{46}$

Die behoud van die El Alamein-vesting het beteken dat die El Alamein-linie staande gebly het in die kritieke stadium op 1 Julie toe die Agste Leër se pantser nog vanaf Mersa Matruh op pad was. Die El Alameinvesting sou van daardie oomblik af ook ' $n$ voortdurende doring in die vlees van Rommel wees. Vanuit die vesting sou SuidAfrikaanse artillerievuur en strooptogte tot die einde van Julie 1942 met die Spilmagte se operasies inmeng. ${ }^{47}$

\section{ROMMEL SE TWEEDE AANSLAG, 2-3 JULIE 1942}

Die gevaar was egter nog nie verby nie. Rommel het op 2 en 3 Julie herhaaldelik gepoog om met die Afrika Korps en die 90ste Ligte Divisie op die Ruweisat-rug deur te breek. Die hoofgeveg het tussen die Duitse magte en die Eerste Britse Pantserdivisie op die rug plaasgevind, maar die Eerste Suid-Afrikaanse Brigade was ook betrokke deurdat die linkerflank van die Duitse magte met hulle gebots het.

Op 2 Julie het die Eerste Suid-Afrikaanse Brigade behoorlik deurgeloop. Drie offisiere en 14 onderoffisiere en manskappe is gewond, insluitende die brigadebevelvoerder, brig. J.P.A. Furstenburg. ${ }^{43}$ Verder is die Sewende Veldregiment se kanonne sodanig beskadig dat hulle teen die einde van die dag nie meer aan die geveg kon deelneem nie. ${ }^{49}$
Die behoud van hierdie stellings op 2 Julie was van besondere betekenis. Dit het die Spilmagte verhoed om die El Alameinvesting te omvleuel en vanuit 'n oostelike rigting aan te val, waar die Derde SuidAfrikaanse Brigade se stellings swak ontwikkel was.

Pienaar was egter bekommerd oor die Suid-Afrikaners se posisie, omdat hy nie wou toesien dat dieselfde lot hulle tref as die Indiërs by Deir el Shein die vorige dag nie. Die Derde Brigade in die El Alameinvesting en die Tweede Brigade het wel nie in die brandpunt van gebeure gestaan nie. In die vesting het hulle in hierdie tyd slegs met flouerige Italiaanse vaspenaanvalle te doen gehad, terwyl die Tweede Brigade andersins glad nie by gevegte betrokke was nie. Diè twee brigades se artillerie het wel bestokingstake uitgevoer. Indien die Eerste Brigade se stellings egter in duie stort, sou hierdie twee brigades se posisies onhoudbaar word, omdat die vyand hulle vanuit die suide sou kon omvleuel.

Dit het teen die middag van 2 Julie geblyk dat die Eerste Brigade se posisie haas onverdedigbaar geword het. Sonder genoeg artillerie sou die Eerste SuidAfrikaanse Brigade kwalik nog 'n dag kon uithou. Die beloofde Britse kolonne wat die Eerste Brigade sou ondersteun, het glad nie opgedaag nie. Die Duitse magte se artillerievuur was besonder effektief en die moontlikheid het bestaan dat die tenks van die Afrika Korps noordoos kon swaai en die Suid-Afrikaners, wat nie genoeg tenkafweerwapens gehad het nie, kon oorrompel. Terselfdertyd het die Eerste Britse Pantserdivisie ' $n$ omvleuelingsbeweging teenoor die Afrika Korps probeer uitvoer. Dit het meegebring dat ' $n$ gaping tussen hulle en die Eerste Suid-Afrikaanse Brigade ontstaan het. ${ }^{50}$ Hierdeur is die reeds kwesbare Suid-Afrikaanse Brigade se suidelike flank ook nog ontbloot.

Pienaar het besluit dat die enigste uitweg was om die Eerste Brigade na veiliger stellings te verskuif. Dit het tot 'n ernstige botsing en woordewisseling met die korpsbevelvoerder van die 30ste Korps, It.-genl. C.W.M. Norrie gelei. Na vele argumente gedurende die nag van $2 / 3$ Julie, waarby Auchinleck uiteindelik ook betrek is, het Pienaar sy sin gekry en is die brigade verskuif. ${ }^{51}$

Dat Pienaar korrek opgetree het deur daarop aan te dring dat die Brigade na 'n 


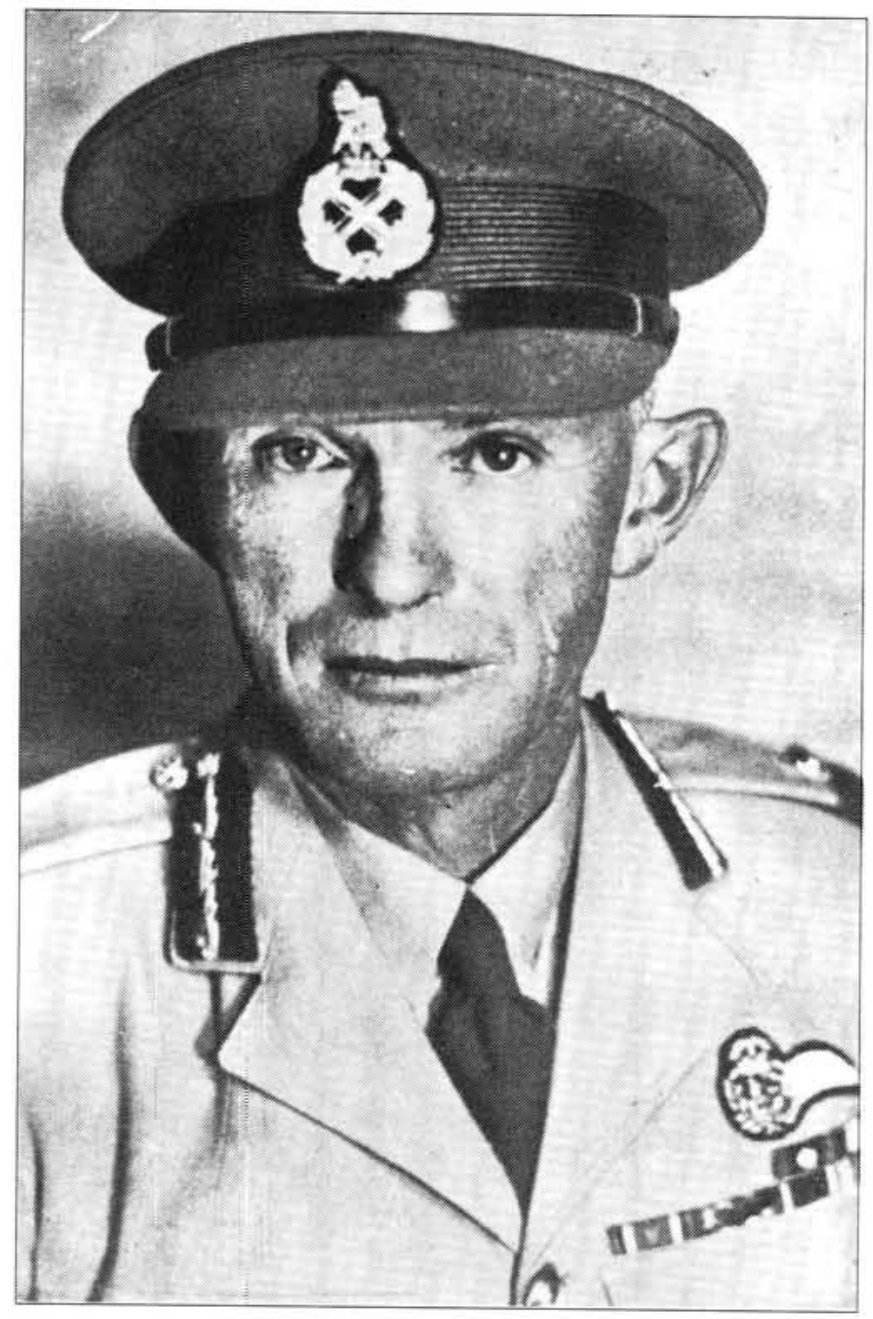

Genl.-maj. D.H. Pienaar, bevelvoerder 1 SA Divisie, Julie 1942. Foto: Direktoraat Dokumentasiediens, SAW.

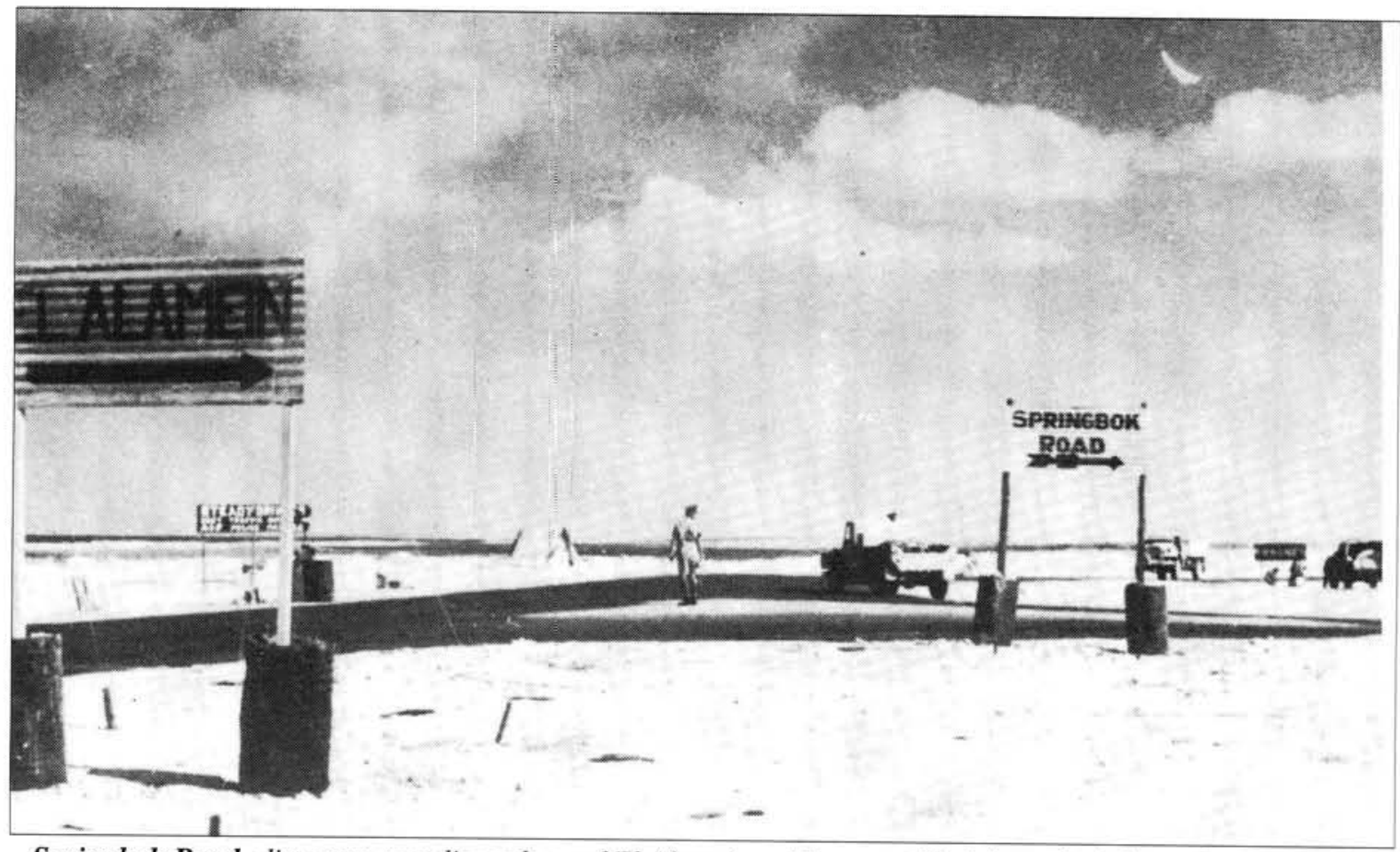

Springbok Road, die naam van die pad vanaf El Alamein suidwaarts. Dit dui op die belangrike rol wat die Suid-Afrikaners in hierdie omgewing gespeel het. 
beter posisie verskuif, is gewis. Die Eerste Suid-Afrikaanse Brigade sou deur ' $n$ kolonne van die Britse 50ste Divisie genaamd Ackol vervang word, terwyl die SuidAfrikaners verder ooswaarts verskuif het. ${ }^{52}$ Die Britse kolonne moes op 3 Julie vinnig die aftog teen die Duitse aanslag blaas, wat bewys het dat sy standpunt, dat die stellings nie behou kon word nie, korrek was. ${ }^{53}$ Pienaar het in 'n stadium getwyfel of hy nie 'n onnodige bohaai opgeskop het oor die kwesbaarheid van die Eerste Brigade nie. Indien die Britse kolonne die stellings kon behou sou hy na ' $n$ gek gelyk het. Kol. E.P. Hartshorne, 'n Suid-Afrikaanse offisier, het Pienaar se verligting soos volg beskryf: "His answer came, certainly and devastatingly, the moment the British column halted. The whole desert erupted in a bloody heap and engulfed the Hot Box. The survivors broke and ran. 'Man,' Dan told me, 'it was terrible. To see the whole bloody column, trucks, guns, ambulances, staff cars driving in as if they were on the parade ground. Then Jerry let them have it. I knew then that I had done the right thing!'”54

\section{ROMMEL OP DIE VERDEDIGING}

Rommel was weens die verliese van die voorafgaande tydperk teen 4 Julie verplig om te verdedig en meer Italiaanse troepe op die front te ontplooi, sodat die Duitse magte kon rus en voorberei vir sy volgende beplande aanval. Auchinleck, wat besef het dat diè magte nie van dieselfde gehalte as die Duitsers was nie, het sy aanvalle van toe af op die Italianers toegespits om so die Spilmagte se linie te laat verbrokkel. Vanaf 4 tot 7 Julie het die Suid-Afrikaners die belangrike taak gehad om deur middel van patrollies krygsgevangenes te neem om sodoende te bepaal waar die Italiaanse magte ontplooi was. $^{55}$

Genl. Auchinleck het die geleentheid benut om van 4 tot 7 Julie beperkte teenaanvalle te laat uitvoer. Dit het die Spilmagte verder verswak, maar nie verslaan nie. Gevolglik het Auchinleck die Negende Australiese Divisie vanaf die Nyldelta ontbied vir die verowering van Tell el Eisa. Vanaf hierdie lae heuwel wes van El Alamein, sou Rommel se kommunikasielyne teen die kus bedreig kon word. Rommel het terselfdertyd beplan om by Bab el Qattara deur te breek. Auchinleck se aanval het egter eerste begin en van 10 tot 12 Julie moes Rommel alles in die stryd werp om te verhoed dat die Australiërs teen die kus deurbreek, sy hoofkwartier oorrompel en sy verbindings afsny. ${ }^{56}$

Die Suid-Afrikaners se behoud van die El Alamein-vesting het die Australiese verowering van Tell el Eisa vergemaklik. Die Ausies het die vesting as afspringplek vir hulle aanval reg wes teen die kus gebruik. Verder het die Suid-Afrikaanse Artillerie waardevolle steun aan die Australiërs verleen. Die Suid-Afrikaanse aanval op Tell el Makh Khad, die suidoostelike uitloper van Tell el Eisa, op 10 Julie, het ook die Australiërs se flank beskerm en hulle aanval vergemaklik. $^{57}$

Op 5 Julie het It.-genl. W.H.C. Ramsden vir Norrie as korpsbevelvoerder vervang en is die Suid-Afrikaanse divisie met die Britse 79 ste Tenkafweerregiment versterk. ${ }^{58}$ Hierdie nuwe aanstelling het niks goeds voorspel vir verhoudinge met die korpshoofkwartier nie. Pienaar en Ramsden het reeds gedurende Mei by Gazala swaarde gekruis oor die aanwending van troepe en laasgenoemde is veral gewantrou omdat hy lief was om sy troepe blindelings, met gevolglike hoë lewensverlies, teen die vyand in te werp. Dit het hom die onvleiende bynaam van "Chuck-em-inRamsden" onder die Suid-Afrikaners besorg. ${ }^{59}$

Ramsden wou hê dat die Suid-Afrikaners so gou as moonlik 'n aktiewer rol moes speel om die druk op die Australiërs by Tell el Eisa te verlig. Sy aandrang hierop het byna tot ' $n$ fiasko gelei.

'n Strooptogmag van hoofsaaklik SuidAfrikaanse troepe, ondersteun deur 17 Britse tenks, is op aandrang van Ramsden onder bevel van brig. Matie du Toit die bevelvoerder van die Tweede Suid-Afrikaanse Brigade saamgestel. Die kolonne sou vanuit die El Alamein-vesting in ' $n$ suidwestelike rigting beweeg. Hulle mikpunt was die Miteiriya-rug suid van Tell el Eisa. Die vyand moes van die westelike deel van die rug af gedryf word en die kolonne moes ' $n$ basis daar inrig, vanwaar strooptogte in 'n suidelike rigting uitgevoer sou word. Ramsden het gehoop om hierdeur van die vyandelike magte te bind en sodoende hulle aanslag op die Australiërs te verswak.

Ramsden se taktlose skimpe dat die SuidAfrikaners nie hulle kant gebring het nie, het waarskynlik meegebring dat Pienaar 


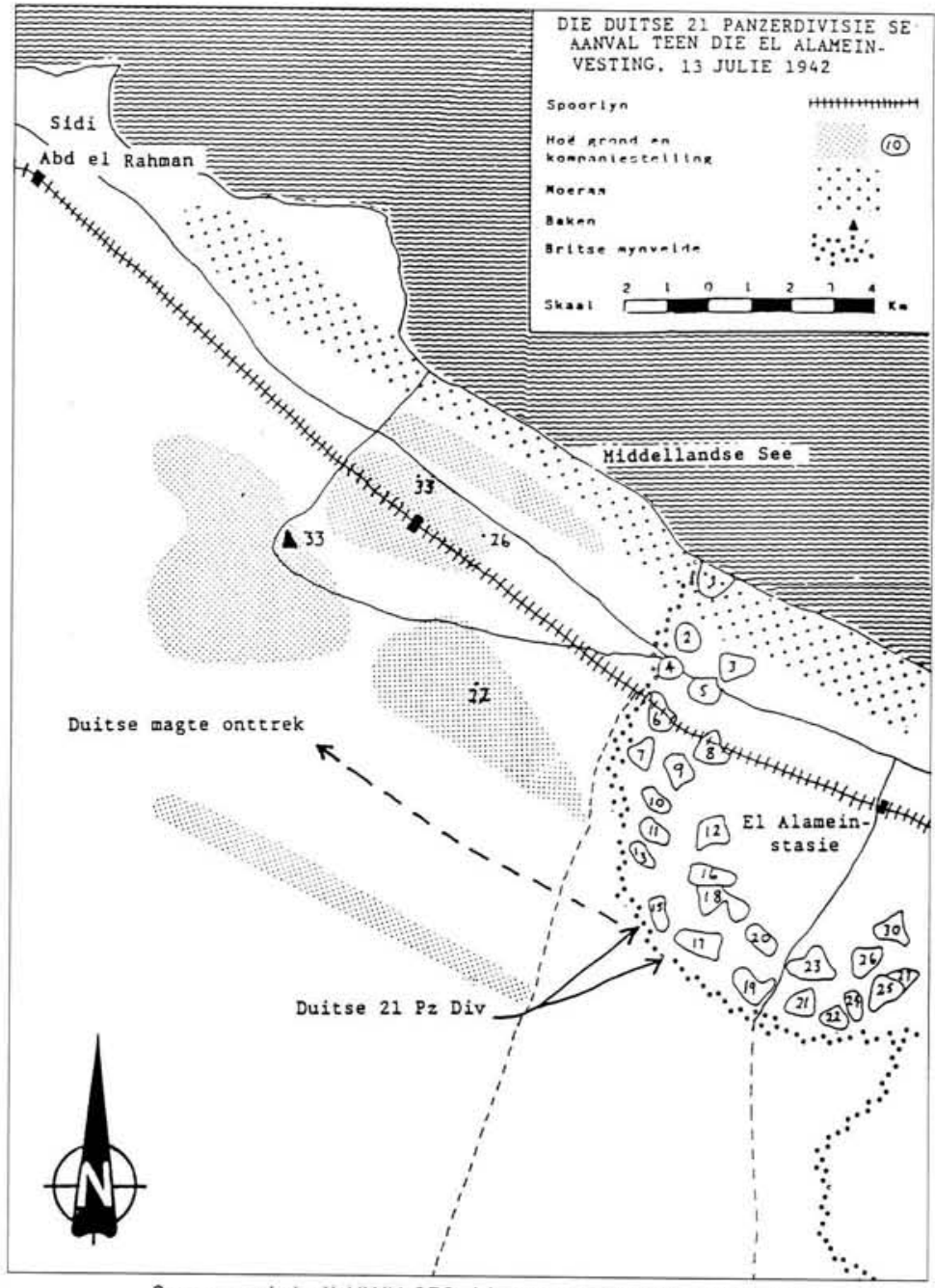

Saamgestel uit UWH 378. Map no. 5: Northern Sector situation 13th July 1942

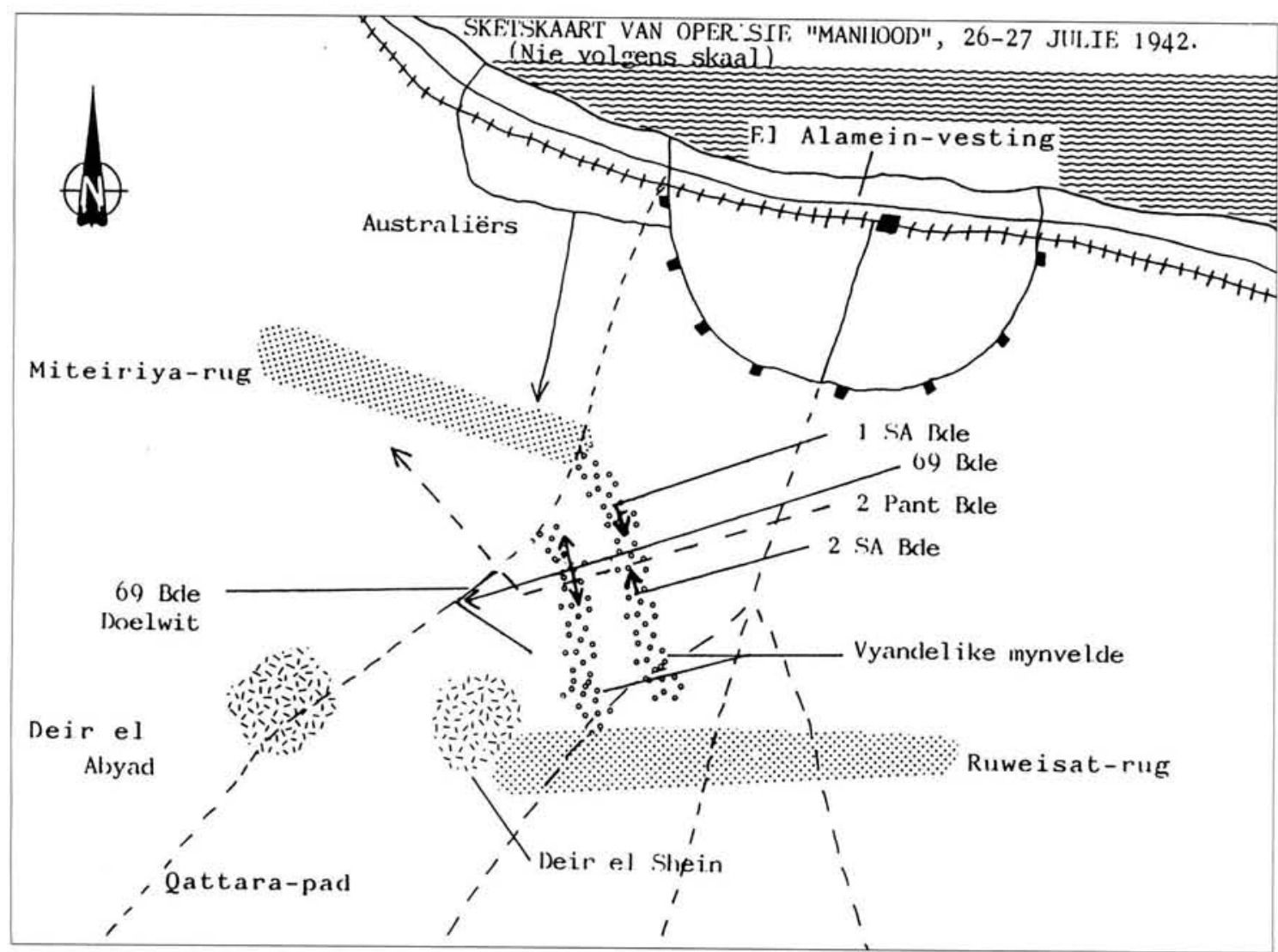

Saamgestel uit SAW Argief, W.D. 347, Lêer A3/ME37: Oorlogsdagboek 1 SA Div HK, 25-27Julie 1942 
teen sy beterwete in tot die operasie ingestem het. Die Suid-Afrikaners het nie genoeg tyd gekry om voor te berei nie en alhoewel die aanvangstyd vir die operasie later uitgestel is, was daar nog nie genoeg tyd om deeglike skakeling tussen die verskillende komponente te bewerkstellig nie. Verder moes daar oor onbekende terrein beweeg word. Die Britse tenks se onbeholpe optrede het in elk geval verseker dat die operasie reeds in die beginstadium gedoem was.

Die kolonne het nie verder as een kilometer buite die vesting gevorder nie toe hulle probleme op die lyf geloop het. Die Britse tenks het te gou begin beweeg, sonder dat hulle opdrag daartoe van Du Toit ontvang het. Hy was nog op pad om met hulle te skakel toe hulle begin beweeg. sonder dat hulle geweet het dat die aanval later sou plaasvind. Drie Britse tenks is raakgeskiet terwyl hulle in 'n mynveld vasgepen is, die ander het meganiese probleme ondervind. Die Eerste SuidAfrikaanse Veldregiment, wat die strooptog moes ondersteun, het ook te gou begin skiet en toe hulle vuursteun broodnodig was, het hulle te min ammunisie oorgehad. Gelukkig het Ramsden ingesien dat sy plan nie werk nie en kon die mag vroegtydig onttrek. Behalwe skade aan die Britse tenks, is geen ander verliese gely nie. ${ }^{00}$ So 'n operasie het deeglike beplanning, skakeling en inoefening vereis en Ramsden se aandrang daarop dat die operasie gou moes begin was dus roekeloos en onverantwoordelik.

\section{ROMMEL SE AANSLAG TEEN DIE EL ALAMEIN-VESTING OP 13 JULIE 1942}

Op 13 Julie het die Suid-Afrikaners skielik weer in die brandpunt van die geveg gestaan. Rommel het ' $n$ desperate poging aangewend om die Australiërs van die res van die Agste Leër af te sny deur 'n direkte aanval op die El Alamein-vesting met die Duitse 21 ste Panzerdivisie, ondersteun deur die Tweede Panzer Grenadier-regiment 104, te loods. Die Royal Durban Light Infantry moes met onvoldoende tenkafweerwapens herhaalde aanslae van die Duitsers afweer. Hulle taak is veral bemoeilik omdat die Duitse artillerie die Suid-Afrikaners se telefoonkabels op verskeie plekke afgeskiet het en die hewigheid van hulle vuur die herstel daarvan bemoeilik het. Dit het vuurleiding aan die Suid-Afrikaanse artillerie bemoeilik. ${ }^{\circ 1}$
Desnieteenstaande het die Suid-Afrikaners aanslag op aanslag op hulle eie afgeweer. Hulp van ander Britse formasies was egter om $16 \mathrm{~h} 10$ nodig toe Duitse tenks ondersteun deur duikbomwerpers, tot 300meter van die Suid-Afrikaanse stellings af gevorder het. Die Negende Australiese Divisie se veldartillerie en die Britse Sewende Medium Artillerie-regiment in die El Alamein-vesting se hulp is toe ingeroep om die Duitse aanval te help afweer. ${ }^{62}$ Teen laaste lig is ook die Britse 79ste Tenkafweerregiment in die westelike deel van die vesting ontplooi, maar in daardie stadium het Rommel reeds die aftog geblaas. ${ }^{63}$

Die Suid-Afrikaanse verliese op 13 Julie was nege gesneuweldes en 42 gewondes. ${ }^{\circ 4}$ Alhoewel hulle verliese nie buitensporig hoog was nie, hulle heldhaftige optrede op 13 Julie was van besondere betekenis. Die verlies van die El Alamein-vesting sou in daardie stadium verreikende gevolge vir die Agste Leër ingehou het. Die gat in die Agste Leër se verdedig-ingslinie sou nie net 'n terugtog na die Nyldelta genoodsaak het nie. Daarmee sou die 24ste Australiese Brigade van die res van die Britse magte afgesny gewees het, wat die Spilmagte 'n redelike kans sou gebied het om hulle te verslaan. Auch-inleck sou dan ook sonder hierdie brigade die Nyldelta moes verdedig.

\section{AUCHINLECK BESLUIT OM PANZERARMEE AFRIKA TE VERNIETIG}

Auchinleck het teen 14 Julie besluit om sy strategie te wysig. Die aankoms var versterkings vanaf Brittanje sedert die begir van die maand en die Britse Oorlogs kabinet se versekering op 12 Julie dat dit nog lank sou duur voordat die Duitse magte in Rusland moontlik die Midde Ooste via Kaukasië kon bereik, het aar hom die geleentheid gebied om meer of fensief op te tree. Hy kon nou ook van die magte in Irak en Persië gebruik om die Agste Leër te versterk sodat laasgenoem de offensief kon optree. Drie pogings is to die einde van die maand aangewend om deur die Spilmagte se linies te breek er hulle te vernietig of terug te dryf.

Rommel het egter gedurende die tweede helfte van Julie getoon dat hy nie net ' $r$ goeie aanvaller was nie, maar ook in die verdediging uitgeblink het. Die Duitse defensiewe taktiek het elke poging var Auchinleck gefrustreer. 
Alhoewel Auchinleck nie Rommel se magte kon veslaan nie, het die Britte nogtans heelwat lesse geleer oor Rommel se defensiewe metodes. Dit was veral Romel se gebruik van ekstensiewe mynvelde, gedek deur infanterie en klein, mobiele pantserformasies, wat die Agste Leër hoofberekenings besorg het. Gegrond op hierdie ervaring kon Montgomery later teenvoeters hierteen vind. ${ }^{65}$

Die Agste Leër, wat tot 13 Julie 1942 in die verdediging uitgeblink het, was nog nie gereed om hierdie tipe operasie suksesvol uit te voer nie. Die samewerking tussen die verskillende dienswapens, veral tussen die infanterie en pantser, was swak. Verder was die Britse bevelvoerders te onbuigsaam om op kritieke oomblikke aanpassings te maak, sodat Rommel se magte van elke terugslag kon herstel en hulle posisies behou het. Die Britse bevelvoerders het voor El Alamein die fout gemaak, om op 'n roekelose wyse hulle tenks, sonder steun van die artillerie en die infanterie, teen die Duitsers in te stoot, wat hulle die maklike prooi van die kranige Duitse tenkafweerkanonniers gemaak het. Gedurende Julie 1942 was hulle egter weer oorversigtig om onmiddellik hulle tenks te gebruik wanneer daar ' $n$ swakplek in die Spilmagte se linie ontstaan het.

Alhoewel die El Alamein-vesting steeds ' $n$ belangrike komponent van die Britse verdedigingslinie gevorm het, het die operasies vanaf 14 tot 23 Julie hoofsaaklik in die omgewing van die Ruweisat-rug plaasgevind. ${ }^{60}$ Tydens hierdie aanvalle het die Suid-Afrikaners in 'n ondersteunende rol opgetree. Die artillerie het deurgaans aan die Australiërs ten noordweste en die Indiërs ten suide van die Suid-Afrikaanse stellings vuursteun gelewer. Strooptogte is teen die vyandelike linies uitgevoer terwyl 'n taakmag onder bevel van It.-kol. C. Cochran van Regiment Botha ' $n$ belangrike funksie vervul het deur die Vyfde Indiese Brigade se noordelike flank tot 28 Julie te beskerm. ${ }^{67}$ Dit is interessant om daarop te let dat die Suid-Afrikaners se verliese tydens hierdie tydperk hoër was as in die voorafgaande. ${ }^{68}$ Die belangrikste rede hiervoor was die hoër vuurkrag waarmee verdedigers aanvalle kon afslaan omdat artillerie en mortiere die dominante wapens tydens die Eerste Slag van El Alamein was. Dit was dus net mooi die omgekeerde van wat met die SuidAfrikaners op 1 Julie gebeur het.
Operasie "Manhood", wat gedurende die nag van 26/27 Julie plaasgevind het, het die Suid-Afrikaners weer direk betrek. Die Suid-Afrikaners moes ' $n$ bres slaan in die eerste van twee vyandelike mynvelde tussen die Miteiriya- en Ruweisat-rûe. Die Britse 69ste Infanteriebrigade sou deur die opening beweeg en ' $n$ gaping in die tweede mynveld maak, waardeur die Britse pantser deur die Spilmagte se linies kon breek. ${ }^{69}$

Die operasie was egter ' $n$ mislukking. Die belangrikste rede hiervoor was dat die Britse pantser nie betyds deur die gapings in die mynvelde beweeg het nie. Toe hulle dit uiteindelik gedoen het, was die element van verrassing verlore en het die Duitse tenkafweerkanonne hulle teruggedryf. Dit het die 69ste Brigade sonder enige steun gelaat en gevolglik is hulle vernietig. ${ }^{70}$

Van Britse kant was daar beskuldigings dat die Suid-Afrikaners verantwoordelik was vir die mislukking van die operasie, aangesien hulle nie volgens beplanning die bres teen 00h01 op 27 Julie voltooi het nie., ${ }^{71}$ Dit is wel waar dat die Suid-Afrikaners nie op daardie tydstip die bres tot die volle voorgeskrewe breedte van 600 meter voltooi het nie. Dit was egter onrealisties om tydens so ' $n$ moeilike en gevaarlike nagtelike operasie te verwag dat voorskrifte tot op die letter nagekom moes word. ${ }^{72}$ Daar was teen $01 \mathrm{~h} 30$ wel twee gapings, van 15 meter en 30 meter onderskeidelik, wat groot genoeg was vir die Britse infanterie om deur te beweeg. Die probleem was eerder die koppigheid van die Britse offisiere, wat nie die SuidAfrikaanse gidse wou glo ten opsigte van die ligging van die suidelike gaping nie. Hulle het gevolglik ' $n$ deel van hulle mag deur ' $n$ onveilige deel van die mynveld laat beweeg en in die proses baie tyd verloor. ${ }^{73}$

Die volgende probleem was dat die Britse pantser nie opdrag gekry het om op ' $n$ spesifieke tyd deur die gapings in die mynvelde te beweeg nie en dit volgens die diskresie van hulle bevelvoerder sou doen. Pienaar, wat besef het wat op die spel was, het by hom aangedring dat sy tenks moes beweeg, maar hy en Ramsden het tyd verkwis omdat hulle self die gapings wou inspekteer en nie Pienaar se woord wou aanvaar nie. Die gevolg was dat die Britse tenks, in stede van om voor eerste lig. helder oordag (om 11hoo) deur die 
gapings beweeg het, reg in die vuur van die wagtende Duitse tenkafweerkanonne in. ${ }^{74}$

Die vernietiging van die Britse 69ste Brigade moet ook voor die deur van die Britse generaals gelê word. Afgesien van die tyd wat hulle verkwis het, het hulle beplanning veel te wense oorgelaat. Ramsden het die Britse infanterie in ' $n$ onbekende gebied ingestuur, sonder om eers die moeite te doen om lugfoto's van die terrein, wat in sy besit was, te bestudeer. ${ }^{75}$ Sy grootste flater was egter dat die brigade buite effektiewe aanwendingsafstand van die Britse medium artillerie in die El Alamein-vesting was, ${ }^{76}$ sodat hulle slegs op hulle eie veldartillerie aangewese was. Aangesien beide die Suid-Afrikaners en die Australiërs hulle veldartillerie self tydens die operasie benodig het, was die implikasie dat die Britse infanterie te min ondersteuningsvuur gehad het.

Genl.-maj. Pienaar kan miskien gekritiseer word omdat hy nie aan Ramsden se versoek, dat die Suid-Afrikaners in beide mynvelde bresse moes slaan, gehoor wou gee nie. Dit sou die kommunikasieprobleem tydens die beweging deur die eerste gaping uitgeskakel het, terwyl die Suid-Afrikaanse artillerie makliker steun in die gebied van die tweede vyandelike mynveld kon verleen het. Pienaar se wantroue in Ramsden het hom egter hierteen laat verset. Op die keper beskou, was dit die beste besluit, omdat die SuidAfrikaanse verliese heelwat hoër sou gewees het. Pienaar kon wel eerder die taakmag wat die gaping moes maak uit net een brigade getrek het. Die gebruik van twee taakmagte, wat van twee verskillende punte af na mekaar toe vir myne moes soek, het meegebring dat, in plaas van een groot gaping, twee kleineres ontstaan het. ${ }^{77}$ Alles in ag genome, is dit egter te betwyfel of dit ' $n$ groot verskil aan die resultaat sou maak. Die Britse generaals dus kan grotendeels hulself blameer vir die mislukking van Operasie "Manhood".

\section{DIE AGSTE LEËR OP DIE VERDEDIGING, 28 JULIE 1942}

Teen 28 Julie het genl. Auchinleck besluit om af te sien van sy pogings om Panzerarmee Afrika te vernietig. Die Britse magte het reeds hoë verliese gely en die Spilmagte se krag was aan die opbou. ${ }^{78}$ Terselfdertyd was die tempo waarteen versterkings in die Midde-Ooste aangekom het so stadig dat ' $n$ Britse offensief voor die middel van September 1942 buite die kwessie was. Gevolglik is instruksies aan die korpsbevelvoers uitgereik om ' $n$ voor te berei om te verdedig. Daarmee was die Eerste Slag van El Alamein afgehandel. ${ }^{79}$

\section{SLOT}

Van die Agste Leër is 12700 offisiere en manskappe gedurende Julie 1942 dood gewond of vermis. ${ }^{80}$ Die totale SuidAfrikaanse verliese, vanaf 26 Junie tot $3 C$ Julie 1942, was 433 offsiere en manskappe waarvan 164 dood, 253 gewond, agt krygsgevangene geneem is en agt behandeling vir bomskok ontvang het. ${ }^{81}$ Die SuidAfrikaanse verliese was dus relatief klein Die redes hiervoor was enersyds, omda die volle aanslag van die Duitse tenks ne op 13 Julie spesifiek teen hulle gemik was en andersyds omdat genl.-maj. Pienaaı vasbeslote was dat hy nie ' $n$ herhaling var Tobroek of Deir el Shein wou hê nie Verder het die gekonsentreerde aanwending van artillerie die Britse magte se vuurkrag in die verdediging verhoog, wat enige vyandige aanvaller se taak be moeilik het.

Wrywing tussen die Suid-Afrikaanse er Britse offisiere was om 'n verskeidenheic van redes eintlik onvermydelik. Hoewel die Suid-Afrikaners se verliese relatief klein was was hulle bevelvoerders uiters sensitiet hiervoor. Bewus daarvan dat hulle uit ' $r$ klein bevolking afkomstig was, wat of sigself skerp verdeel was oor die land $s \in$ deelname aan die oorlog, het hulle deurgaans hulle troepe se welsyn voorop gestel. Hulle was nie bereid om sonde meer in ondeurdagte gevegsituasies betrokke te raak waar hoë lewensverlie: onvermydelik sou wees nie. Bowendier was die oorgawe by Tobroek 'n pynlike ervaring wat nie herhaal moes word nie Hiervoor het die Britse bevelvoerders nie altyd begrip gehad nie.

Dit is dus duidelik dat die Eerste SuidAfrikaanse Divisie tydens die slag ' belangrike rol gespeel het, maar hulle aandeel moet in perspektief gesien word Die divisie het wel op 1 Julie 'n belangrike funksie vervul, maar hulle sou waarskynlih swaarder verliese gely het sonder die heldhaftige optrede van die 18de Indiese Brigade by Deir el Shein. Die Indiërs wa: die spreekwoordelike soenoffer waarmee die Duitse Afrika Korps gestuit is. Sonder die 
hulp van die Britse pantser op die Ruweisat-rug en die Britse en Australiese artillerie sou die Suid-Afrikaners dalk nie op 13 Julie alleen die El Alamein-vesting kon behou het nie. Vandat die Australiërs die Tell el Eisa-heuwel op 10 Julie verower het, was hulle meestal in die brandpunt van gebeure. Die Suid-Afrikaners het net op 13 Julie en tydens Operasie "Manhood", 'n beduidende rol gespeel.

Die belangrikheid van die Suid-Afrikaners se bydrae was daarin geleë dat dit deel van 'n spanpoging was. Hulle bydrae het gehelp dat Rommel gestuit is en Alexandrië, die Suez-kanaal en die olievelde van die Persiese Golf in Britse hande gebly het. Dit was van kardinale belang vir die Geallieerde oorlogspoging, omdat dit die Britse Ryk in staat gestel het om uiteindelik, saam met hulle Amerikaanse bondgenote, die Spilmagte uit Noord-Afrika te verdryf.

Die Eerste Suid-Afrikaanse Divisie het dus ook ' $n$ belangrike bydrae gelewer om ' $n$ politieke doel van die Smuts-regering te verwesenlik, naamlik dat die Unieverdedigingsmag 'n rol moes speel in diè oorlogsteater wat vir die Britse Ryk van lewensbelang was.

* Kmat. C.J. Jacobs is tans ' $\mathrm{n}$ navorser in Krygsgeskiedenis by die Dokumentasiediens, SAW. Hierdie artikel is "n wysiging van die een wat in Historia 36(2) van November 1991 verskyn.

\section{Bibliografie}

1. C.F.J. Muller(red.): Vyfhonderd Jaar SuidAfrikaanse Geskiedenis, pp. $452-453$ (B.J. Liebenberg: Smuts aan bewind, 1939-1948).

2. W.K. Hancock : Smuts, Vol. II, pp.366-367

3. M. Howard: The Mediterranean Strategy in the Second World War, pp.7-8.

4. W.K. Hancock : Smuts, Vol. II, pp.366-367.

5. P. Calvocoressi and G. Wint : Total War, pp.397398. Kyk kaart.

6. London Gazette, 15.1.1948, Sup-plement, p.328 (Gen Sir Claude J.E. Auchinleck : Despatch to the Secretary of State for War on 27th January 1943).

B.H. Liddell Hart : History of the Second World War, pp.290-291.

8. Kyk aangehegte kaarte.

I.S.O. Playfair, et al : The Mediterranean and Middle East, Vol.III, p.332.
10. C. Barnett : The Desert Generals, p. 195.

11. Kyk aangehegte diagram.

12. Kyk aangehegte kaart.

13. J.A.I. Agar-Hamilton and L.C.F. Turner : Crisis in the Desert, p.271.

14. J.A.I. Agar-Hamilton and L.C.F. Turner : Crisis in the Desert, p.271.

15. Purnell's History of the Second World War, No. 7. Vol. 3/6, 1967, p.1062 (E. Dorman O'Gowan: ist Alamein - The Battle that saved Cairo).

16. R.W. Tungay : The Fighting Third, p.238.

17. War Monthly, no. 22, January 1976, p.36 (H. Essame : First Alamein).

18. P.C. Barucha : The North African Campaign, 1940-1943, p.417

19. K. Macksey: Afrika Korps, p.94.

20. Saamgestel uit SAW Argief, UWH 177, Lêer 22926/1 : War Diary Deutsches Afrika Korps, 30 June 1942 en Purnell's History of the Second World War, No. 7. Vol. 3/6, 1967, p. 1070 (E. Dorman O'Gowan: 1st Alamein - The Battle that saved Cairo).

21. M. van Creveld : Supplying War, pp.194-197.

22. S. Bidwell and D. Graham : Fire-Power, p.239.

23. K. Macksey : Afrika Korps, p.94

24. B.H. Liddell Hart : History of the Second World War, pp. 187-188.

25. I.S.O. Playfair, et al : The Mediterranean and Middle East, Vol. III, p.333.

26. S. Bidwell : Gunners at War, p.163.

27. D. Richards and H. St. George Saunders : Royal Air Force, Vol. II, p.219.

28. C. Barnett : The Desert Generals, pp. 189-199.

29. B.H. Liddell Hart : History of the Second World War, p.239.

30. SAW Argief, Divisional Documents (Div. Docs.) 68. Lêer 64 : Operational Report, 1st SA Division, El Alamein Defensive Battle, 29 June - 30 September 1942, p.2.

\section{D.W. Kruger : The Making of a Nation, p.210.}

32. SAW Argief, Divisional Documents (Div. Docs.) 68. Lêer 64 : Operational Report, 1st SA Division, El Alamein Defensive Battle, 29 June - 30 September 1942, p.2.

33. Saamgestel uit SAW Argief, Div. Docs. 88, Lêer 1 Div 81/A2 : Strenghts; June - October 1942, War Monthly, No. 22, January 1976, p.36 (H. Essame : First Alamein) en Purnell's History of the Second World War, No.7, Vol. 3/6, 1967, p.1 068 (E. Dorman O'Gowan: 1st Alamein - The Battle that saved Cairo).

34. Purnell's History of the Second World War, No.7, Vol. 3/6, 1967, p. 1068 (E. Dorman O'Gowan: 1st Alamein - The Battle that saved Cairo). 
36. SAW Argief, WD 403 Lêer $34374 / 3$ : Report, Panzerarmee Afrika - Commander Southern Front, 1st July 1942.

37. Purnell's History of the Second World War. No.7. Vol. 3/6, 1967, p.1 070 (E. Dorman O'Gowan : Ist Alamein - The Battle that saved Cairo).

38. SAW Argief, WD 358, Lêer $A 7 / M E 52$ : Oorlogsdagboek 3 SA Bde. HK., I Julie 1942.

39. SAW Argief, Div. Docs. 105, Lêer 1 SAD/A2/2 : Battle Casualties, June - July 1942.

40. Saamgestel uit SAW Argief, UWH 3224, UWH Draft Narratives : Radio Message 21st Panzer Division Deutsches Afrika Korps, 05h40, 2nd July 1942 en I.S.O. Playfair, et al: The Mediterranean and Middle East, Vol. III, p.341.

41. I.S.O. Playfair, et al : The Mediterranean and Middle East, Vol. III, pp.339-341.

42. E.P. Hartshorne: Avenge Tobruk, pp. 157-158.

43. Militaria, 10/4, 1980, P.5 (C.L. de W. du Toit : Herinneringe, III).

44. SAW Argief, WD 343, Lêer C28/33 Oorlogsdagboek 1 SA Div. Admin. HK., 1 Julie 1942.

45. D. W. Krüger : The Making of a Nation, p. 211.

46. I.S.O. Playfair, et al : The Mediterranean and Middle East, Vol. III, p.341.

47. J.A.I. Agar-Hamilton and L.C.F. Turner : Crisis in the Desert, p.271.

48. SAW Argief, Div. Docs. 105, Lêer ISAD/A2/2, Battle Casualties, 2 July 1942.

49. SAW Argief, WD 403, Lêer A 15/ME 63 : Oorlogsdagboek 1 Veldregiment SA Artillerie, 2 Julie 1942.

50. SAW Argief, WD 347, Lêer A3/ME37 : Oorlogsdagboek I SA Div. HK., 2 Julie 1942.

51. I.S.O. Playfair, et $a$ : : The Mediterranean and Middle East, Vol. III, p.343.

52. SAW Argief, WD 358, Lêer A6/ME49 Oorlogsdagboek 1 SA Bde. HK., 3 Julie 1942.

53. SAW Argief, WD 358, Lêer A6/ME49 Oorlogsdagboek I SA Bde. HK., 3 Julie 1942.

54. E.P. Hartshorne: Avenge Tobruk, P. 158.

55. SAW Argief, WD 347, Lêer A3/ME37 Oorlogsdagboek 1 SA Div. HK., 2 Julie 1942.

56. I.S.O. Playfair, et al : The Mediterranean and Middle East, Vol. III,pp.338-339.

57. I.S.O. Playfair, et al : The Mediter-ranean and Middle East, Vol. III. pp.345-346.

58. SAW Argief, WD 347, Lêer A3/ME37 : Oorlogsdagboek 1 SA Div. HK., 5 Julie 1942.

59. E.P. Hartshorne : Avenge Tobruk, p. 162.
60. Militaria, 10/4, 1980, pp.8-9 (C.L. de W. du Toit Herinneringe, III).

61. SAW Argief, WD 347, Lêer $A 3 / M E 37$ Oorlogsdagboek 1 SA Div. HK., 13 Julie 1942.

62. SAW Argief, WD 347, Lêer A3/ME 37 Oorlogsdagboek 1 SA Div. HK., 13 Julie 1942.

63. R.W. Tungay: The Fighting Third, pp.252-253.

64. Saamgestel uit : SAW Argief, Erero Wêreldoorlog II, 1939-1945 en SAW Argief, Div. DocS 105, Lêer 1SAD/ A2/2 : Battle Casualties 13 July 1942.

65. Purnell's History of the Second World War No.7, Vol. 3/6, 1967, p.1 072-1 075 (E. Dorman O'Gowan: 1st Alamein - The Battle that saved Cairo)

66. I.S.O. Playfair, et al: The Mediterranean anc Middle East, Vol. III, pp.347-357.

67. SAW Argief, WD 347, Lêer A3/ME37 Oorlogsdagboek 1 SA Div. HK., 12-24 Julie 1942.

68. Saamgestel uit : SAW Argief, Erero Wêreldoorlog II, 1939-1945 en SAW Argief, Div. DocS 105. Lêer 1SAD/ A2/2: Battle Casualties 13-25 Julv 1942.

69. SAW Argief, WD 347, Lêer A3/ME37 Oorlogsdagboek 1SA Div. HK., Appendix, 30th Corp Operational Order no. 68 of 26th July 1942, pp. 1-2.

70. J. Connell : Auchinleck, p.682.

71. I.S.O. Playfair, et al: The Mediter-ranean ane Middle East, Vol. III, p.358.

72. C.E.E. Sloan : Mine warfare on Land, p. 15.

73. SAW Argief, WD 347, Lêer A3/ME37 Oorlogsdagboek ISA Div. HK., Appendix C, Repor 3rd Engineer Field Company, p. 1.

74. SAW Argief, UWH Narratives and Reports, Mic dle East Vol. II. 1st SA Division. Tobruk to El Alameir p.1 (Interview with Col. H.F.C. Cilliers on 26 April 1949)

75. Militaria, 10/4, 1980, P.10 (C.L. de W. du Toit Herinneringe, III),

76. C. Foss : Artillery of the World, p.33. Kyk oo kaart.

77. SAW Argief, UWH Narratives and Reports, Mic dle East Vol. II, Ist SA Division, Tobruk to El Alameir p. 1 (Interview with Col. H.F.C. Cilliers on 26 April 1949)

78. B.H. Liddell Hart : History of the Second Worl War, p.300.

79. I.S.O. Playfair, et al: The Mediterranean an Middle East, Vol. III, p.359.

80. London Gazette, 15.1.1948, Supplement, p.33 (Gen Sir Claude J.E. Auchinleck: Despatch to th Secretary of State for War on 27th January 1943).

81. Saamgestel uit : SAW Argief, Ererc Wêreldoorlog II, 1939-1945 en SAW Argief, Div. Doc 105, Lêer 1SAD/ A2/2 : Battle Casualties 1-30 Ju 1942. 


\section{BRONNE}

\section{Literatuur}

Barnett, C. : The Desert Generals, Second Edition, London, 1983.

Bidwell, S. and D. Graham : Fire Power. British Army Weapons and Theories of War, 1904 - 1945. London. 1982.

Bidwell, S. : Gunners at War. A tactical study of the Royal Artillery in the Twentieth Century. London, 1970.

Calvocoressi, P. and G. Wint : Total War. Volume I, The War in the West. New York, 1973.

Connell, J. : Auchinleck. A Biography of Field - Marshal Sir Claude Auchinleck. London, 1959.

Foss, C.F. : Artillery of the World. London, 1974

Hancock. W.K. : Smuts. Volume II, The Fields of Force, 1919 - 1950, First Edition. Cambridge, 1968.

Howard. M. : The Mediterranean Strategy in the Second World War. London, 1966.

Krüger, D.W. : The Making of a Nation. A History of the Union of South Africa, 1910 - 1961. Pretoria. 1971.

Liddell Hart, B.H. : History of the Second World War, Second Edition. London, 1974

Macksey, K. : Afrika Korps, Second Edition. London, 1968.

Muller, C.F.J. (red.) : Vyfhonderd Jaar Suid-Afrikaanse Geskiedenis, Derde Hersiene Uitgawe. Pretoria en Kaapstad. 1984.

Sloan, C.E.E. : Mine Warfare on Land. London, 1986.

Van Creveld, M. : Supplying War. Logistics from Wallenstein to Patton. London, New York and Melbourne, 1977

Young, P. : Atlas of the Second World War, American Edition. New York, 1974.

\section{Letterkundige Bronne}

Hartshorne, E.P. : Avenge Tobruk. Cape Town and Johannesburg, 1960.

Tungay, R.W. : The Fighting Third. Cape Town, 1947.

Young, D. : Rommel. Glasgow, 1975.

\section{Iydskrif-en Koerantartikels}

Auchinleck, C.J.E. : Despatch by General Sir Claude J.E. Auchinleck, Commander in Chief, Middle East Forces to the Secretary of State for War on 27.1.1943. Operations in the Middle East from 1st November 1941 to 15th August 1942. Supplement to The London Gazette, 13.1.1948.

Dorman O'Gowan, E. : Ist Alamein - The Battle that saved Cairo. Purnell's History of the Second World War, no, 7, 3/6, 1967.
Du Toit, C.L. de W. : Die Herinneringe van Generaal Christiaan Ludolph De Wet Du Toit, Deel III, Militaria, 10/4, 1980.

Essame, H. : First Alamein. War Monthly, 22, January 1976.

\section{Amptelike Publikasies}

Agar-Hamilton, J.A.I. and L.C.F. Turner: Crisis in the Desert, May - July 1942. London, Cape Town and New York, 1952.

Butler, J.R.M. (ed.) : History of the Second World War United Kingdom Military Series (Playfair, I.S.O. C.J.C. Molony, F.C. Flynn, and T.P. Gleave: The Mediterranean and Middle East, Volume III, September 1941 to September 1942. British Fortunes reach their Lowest Ebb. London, 1960).

Prasad, B. (ed.) : Official History of the Indian Armed Forces in the Second World War, 1939-1945. Campaigns in the Western Theatre (Bharucha, P.C. : The North African Campaign, 1940 - 1943. London and Culcutta, 1956).

Richards, D. and H. St. George Saunders : Royal Air Force, 1939 - 1945, Volume II. The Fight Avails. London, 1954.

Argivale Bronne: Suid-Afrikaanse Weermagargief. Pretoria

Divisional Documents(Div. Docs.) 68, Lêer 64 : Operational Report, 1st SA Division, El Alamein Defensive Battle, 29 June - 30 September 1942.

Div. Docs. 88, Lêer 1 Div 81/A2 : Strenghts, June - OCtober 1942.

Div. Docs. 105, Lêer 1 SAD/A2/2 : Battle Casualties, June - July 1942.

Union War Histories(UWH) Narratives and Reports, Middle East, Vol. II, 1st SA Div.. Tobruk to El Alamein.

UWH 324, Lêer $3434 / 3$ Reports, Panzerarmee Afrika Commander Southern Front, July 1942.

UWH 177, Lêer 22926/1 : War Diaries Deutsches Afrika Korps, June and July 1942.

UWH 3224, Draft Narratives : Radio Mes-sage 21st Panzer Division - Deutsches Afrika Korps, 05h40, 2 July 1942.

UWH 378, Maps.

War Diaries(WD) 343, Lêer C28/33 : Oor-logsdagboek Eerste Suid-Afrikaanse Divisie Administratiewe hoofkwartier.

WD 347, Lêer A3/ME37 : Oorlogsdagboek Eerste SuidAfrikaanse Divisie-hoofkwartier.

WD 358, Lêer A6/ME 49 : Oorlogsdagboek Eerste SuidAfrikaanse Brigade-hoofkwartier.

WD 361, Lêer A7/ME 52 : Oorlogsdagboek Derde SuidAfrikaanse Brigade-hoofkwartier.

WD 372, Lêer A15/ME63 : Oorlogsdagboek Eerste Veldregiment, SA Artillerie. 